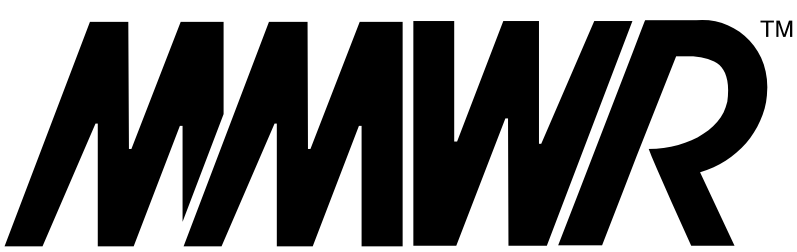

1141 Changes in the Public Health System

1147 Community Needs Assessment and Morbidity Surveillance Following an Earthquake Turkey, August 1999

1150 Imported Dengue - Florida, 1997-1998

MORBIDITY AND MORTALITY WEEKLY REPORT

1153 Notices to Readers

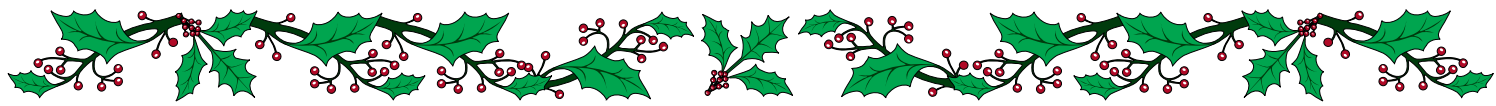

Achievements in Public Health, 1900-1999

\title{
Changes in the Public Health System
}

The 10 public health achievements highlighted in this MMWR series (see box) reflect the successful response of public health to the major causes of morbidity and mortality of the 20th century (1-11). In addition, these achievements demonstrate the ability of public health to meet an increasingly diverse array of public health challenges. This report highlights critical changes in the U.S. public health system this century.

In the early 1900s in the United States, many major health threats were infectious diseases associated with poor hygiene and poor sanitation (e.g., typhoid), diseases associated with poor nutrition (e.g., pellagra and goiter), poor maternal and infant health, and diseases or injuries associated with unsafe workplaces or hazardous occupations $(4,5,7,8)$. The success of the early public health system to incorporate biomedical advances (e.g., vaccinations and antibiotics) and to develop interventions such as health education programs resulted in decreases in the impact in these diseases. However, as the incidence of these diseases decreased, chronic diseases (e.g., cardiovascular disease and cancer) increased $(6,10)$. In the last half of the century,

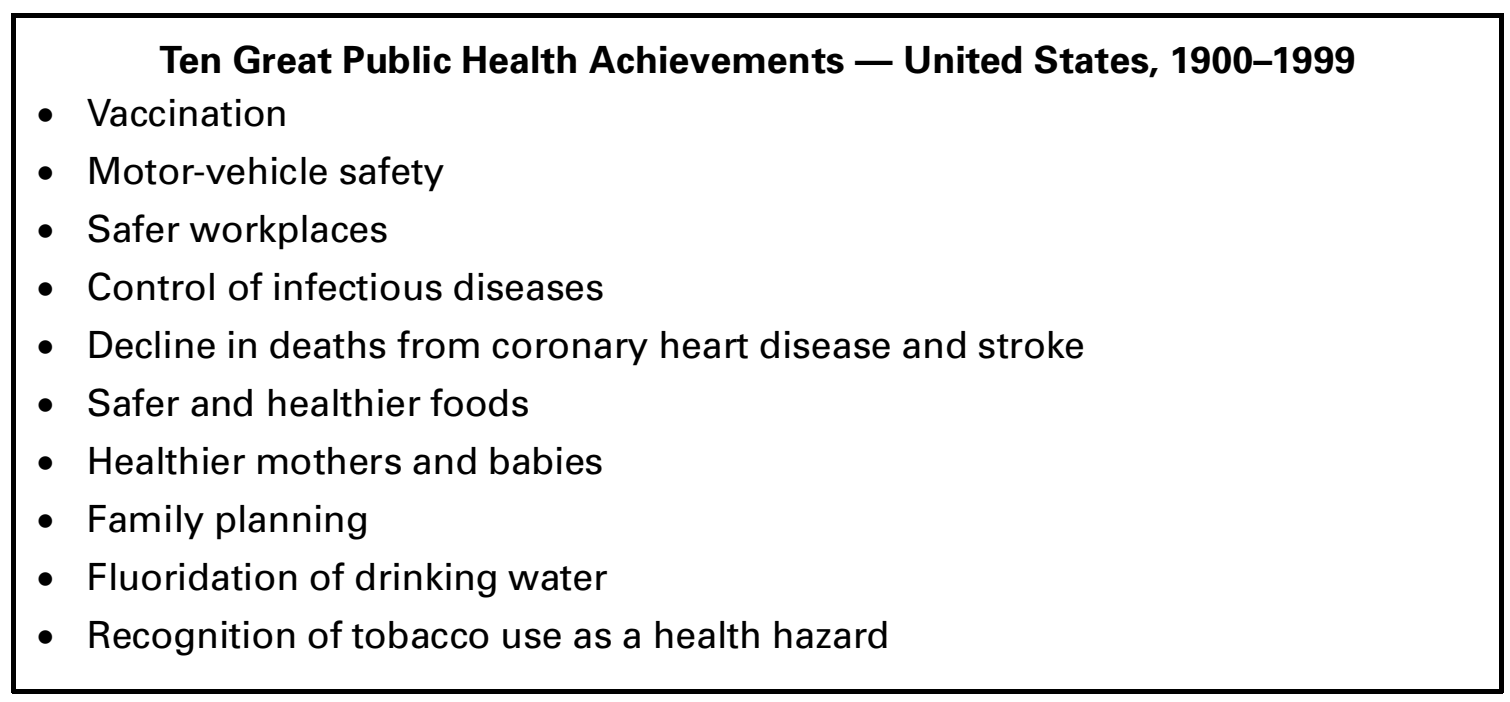

U.S. DEPARTMENT OF HEALTH \& HUMAN SERVICES 
Public Health System - Continued

public health identified the risk factors for many chronic diseases and intervened to reduce mortality. Public efforts also led to reduced deaths attributed to a new technology, the motor vehicle (3). These successes demonstrated the value of community action to address public health issues and have fostered public support for the growth of institutions that are components of the public health infrastructure*. The focus of public health research and programs shifted to respond to the effects of chronic diseases on the public's health (12-17). While continuing to develop and refine interventions, enhanced morbidity and mortality surveillance helped to maintain these earlier successes. The shift in focus led to improved capacity of epidemiology and to changes in public health training and programs.

\section{Quantitative Analytic Techniques}

Epidemiology, the population-based study of disease and an important part of the scientific foundation of public health, acquired greater quantitative capacity during the 20th century. Improvements occurred in both study design and periodic standardized health surveys $(12,18-21)$. Methods of data collection evolved from simple measures of disease prevalence (e.g., field surveys) to complex studies of precise analyses (e.g., cohort studies, case-control studies, and randomized clinical trials) ( 12 ). The first welldeveloped, longitudinal cohort study was conducted in 1947 among the 28,000 residents of Framingham, Massachusetts, many of whom volunteered to be followed over time to determine incidence of heart disease (12). The Framingham Heart Study served as the model for other longitudinal cohort studies and for the concept that biologic, environmental, and behavioral risk factors exist for disease $(6,12)$.

In 1948, modern clinical trials began with publication of a clinical trial of streptomycin therapy for tuberculosis, which employed randomization, selection criteria, predetermined evaluation criteria, and ethical considerations $(19,21)$. In 1950, the casecontrol study gained prominence when this method provided the first solidly scientific evidence of an association between lung cancer and cigarette smoking (22). Subsequently, high-powered statistical tests and analytic computer programs enabled multiple variables collected in large-scale studies to be measured and to the development of tools for mathematical modeling. Advances in epidemiology permitted elucidation of risk factors for heart disease and other chronic diseases and the development of effective interventions.

\section{Periodic Standardized Health Surveys}

In 1921, periodic standardized health surveys began in Hagerstown, Maryland ( 12 ). In 1935, the first national health survey was conducted among U.S. residents $(12,23)$. In 1956, these efforts resulted in the National Health Survey, a population-based survey that evolved from focusing on chronic disease to estimating disease prevalence for major causes of death, measuring the burden of infectious diseases, assessing exposure to environmental toxicants, and measuring the population's vaccination coverage. Other population-based surveys (e.g., Behavioral Risk Factor Surveillance System, Youth Risk Behavior Survey, and the National Survey of Family Growth) were developed to assess risk factors for chronic diseases and other conditions (24-26). Methods developed by social scientists and statisticians to address issues such as sampling and interviewing techniques have enhanced survey methods used in epidemiologic studies (12).

\footnotetext{
*The government, community, professional, voluntary, and academic institutions and organizations that support or conduct public health research or programs.
} 


\section{Public Health System - Continued}

\section{Morbidity and Mortality Surveillance}

National disease monitoring was first conducted in the United States in 1850, when mortality statistics based on death registrations were first published by the federal government (23,27). During 1878-1902, Congress authorized the collection of morbidity reports on cholera, smallpox, plague, and yellow fever for use in quarantine measures, to provide funds to collect and disseminate these data, to expand authority for weekly reporting from states and municipal authorities, and to provide forms for collecting data and publishing reports $(15,23,27)$. The first annual summary of The Notifiable Diseases in 1912 included reports of 10 diseases from 19 states, the District of Columbia, and Hawaii. By 1928, all states, the District of Columbia, Hawaii, and Puerto Rico were participating in the national reporting of 29 diseases. In 1950, state and territorial health officers authorized the Council of State and Territorial Epidemiologists (CSTE) to determine which diseases should be reported to the U.S. Public Health Service (PHS) (27). In 1961, the Centers for Disease Control and Prevention (CDC) assumed responsibility for collecting and publishing nationally notifiable diseases data. As of January 1, 1998, 52 infectious diseases were notifiable at the national level.

In the early 1900s, efforts at surveillance focused on tracking persons with disease; by mid-century, the focus had changed to tracking trends in disease occurrence (28,29 ). In 1947, Alexander Langmuir at the newly formed Communicable Disease Center, the early name for CDC, began the first disease surveillance system (27). In 1955 , surveillance data helped to determine the cause of poliomyelitis among children recently vaccinated with an inactivated vaccine (28). After the first polio cases were recognized, data from the national polio surveillance program confirmed that the cases were linked to one brand of vaccine contaminated with live wild poliovirus. The national vaccine program continued by using supplies from other polio vaccine manufacturers (28). Since these initial disease surveillance efforts, morbidity tracking has become a standard feature of public health infectious disease control (29).

\section{Public Health Training}

In 1916, with the support of the Rockefeller Foundation, the Johns Hopkins School of Hygiene and Public Health was started (30,31). By 1922, Columbia, Harvard, and Yale universities had established schools of public health. In 1969, the number of schools of public health had increased to 12, and in 1999, 29 accredited schools of public health enrolled approximately 15,000 students (31,32). Besides the increase in the number of schools and students, the types of student in public health schools changed. Traditionally, students in public health training already had obtained a medical degree. However, increasing numbers of students entered public health training to obtain a primary postgraduate degree. In 1978, 3753 (69\%) public health students enrolled with only baccalaureates. The proportion of students who were physicians declined from $35 \%$ in $1944-1945$ to $11 \%$ in $1978(28,31)$. Thus, public health training evolved from a second degree for medical professionals to a primary health discipline (33). Schools of public health initially emphasized the study of hygiene and sanitation; subsequently, the study of public health has expanded into five core disciplines: biostatistics, epidemiology, health services administration, health education/ behavioral science, and environmental science (30,34).

Programs also were started to provide field training in epidemiology and public health. In 1948, a board was established to certify training of physicians in public 
Public Health System - Continued

health administration, and by 1951, approximately 40 local health departments had accredited preventive medicine and public residency programs. In 1951, CDC developed the Epidemic Intelligence Service (EIS) to guard against domestic acts of biologic warfare during the Korean conflict and to address common public health threats. Since 1951, more than 2000 EIS officers have responded to requests for epidemiologic assistance within the United States and throughout the world. In 1999, 149 EIS officers are on duty.

\section{Nongovernment and Government Organizations}

At the beginning of the century, many public health initiatives were started and supported by nongovernment organizations. However, as federal, state, and local public health infrastructure expanded, governments' role increased and assumed more responsibility for public health research and programs. Today, public health represents the work of both government and nongovernment organizations.

Nongovernment organizations. The Rockefeller Sanitary Committee's Hookworm Eradication Project conducted during 1910-1920 was one of the earliest voluntary efforts to engage in a campaign for a specific disease (35). During 1914-1933, the Rockefeller Foundation also provided \$2.6 million to support county health departments and sponsored medical education reform. Other early efforts to promote community health include the National Tuberculosis Association work for TB treatment and prevention, the National Consumers League's support of maternal and infant health in the 1920s, the American Red Cross' sponsorship of nutrition programs in the 1930s, and the March of Dimes' support of research in the 1940s and 1950s that led to a successful polio vaccine. Mothers Against Drunk Driving started in 1980 by a group of women in California after a girl was killed by an intoxicated driver and grew into a national campaign for stronger laws against drunk driving.

Professional organizations and labor unions also worked to promote public heath. The American Medical Association advocated better vital statistics and safer foods and drugs (17). The American Dental Association endorsed water fluoridation despite the economic consequences to its members (9). Labor organizations worked for safer workplaces in industry (4). In the 1990s, nongovernment organizations sponsor diverse public health research projects and programs (e.g., family planning, human immunodeficiency virus prevention, vaccine development, and heart disease and cancer prevention).

State health departments. The 1850 Report of the Sanitary Commission of Massachusetts, authored by Lemuel Shattuck $(13,14)$, outlined many elements of the modern public health infrastructure including a recommendation for establishing state and local health boards. Massachusetts formed the first state health department in 1889 . By 1900, 40 states had health departments that made advances in sanitation and microbial sciences available to the public. Later, states also provided other public health interventions: personal health services (e.g., disabled children and maternal and child health care, and sexually transmitted disease treatment), environmental health (e.g., waste management and radiation control), and health resources (e.g., health planning, regulation of health care and emergency services, and health statistics). All states have public health laboratories that provide direct services and oversight functions (36). 


\section{Public Health System - Continued}

County health departments. Although some cities had local public health boards in the early 1900s, no county health departments existed (33). During 1910-1911, the success of a county sanitation campaign to control a severe typhoid epidemic in Yakima County, Washington, created public support for a permanent health service, and a local health department was organized on July 1, 1911 (33). Concurrently, the Rockefeller Sanitary Commission began supporting county hookworm eradication efforts $(17,35)$. By 1920, 131 county health departments had been established; by 1931, 599 county health departments were providing services to one fifth of the U.S. population (33); in 1950, 86\% of the U.S. population was served by a local health department, and 34,895 persons were employed full-time in public health agencies (37).

Local health departments. In 1945, the American Public Health Association proposed six minimum functions of local health departments (38). In 1988, the Institute of Medicine defined these functions as assessment, policy development, and assurance, and PHS has proposed 10 organizational practices to implement the three core functions $(39,40)$. The national health objectives for 2000 , released in 1990, provided a framework to monitor the progress of local health departments (41). In 1993, 2888 local health departments ${ }^{\dagger}$, representing county, city, and district health organizations operated in 3042 U.S. counties. Of the 2079 local health departments surveyed in 1993, nearly all provided vaccination services (96\%) and tuberculosis treatment (86\%); fewer provided family planning (68\%) and cancer prevention programs (54\%) (42).

Federal government. In 1798, the federal government established the Marine Hospital Service to provide health services to seamen (15). To recognize its expanding quarantine duties, in 1902, Congress changed the service's name to the Public Health and Marine Hospital Service and, in 1912, to the Public Health Service. In 1917, PHS' support of state and local public health activities began with a small grant to study rural health (35). During World War I, PHS received resources from Congress to assist states in treating venereal diseases. The Social Security Act of 1935, which authorized health grants to states, and a second Federal Venereal Diseases Control Act in 1938 $(13,14)$, expanded the federal government's role in public health $(15,35)$. In 1939 , PHS and other health, education, and welfare agencies were combined in the Federal Security Agency, forerunner of the Department of Health and Human Services. In the 1930s, the federal government began to provide resources for specific conditions, beginning with care for crippled children. After World War II, the federal role in public health continued to expand with the Hospital Services and Construction Act (HillBurton) of $1946^{\S}$ (15). In 1930, Congress established the National Institutes of Health [formerly the Hygiene Laboratories of the Public Health Service] and the Food and Drug Administration. CDC was established in 1946 (29). Legislation to form Medicare and Medicaid was enacted in 1965, and the Occupational Safety and Health Administration and the Environmental Protection Agency were organized in 1970.

Although federal, state, and local health agencies and services have increased throughout the century, public health resources represent a small proportion of overall health-care costs. In 1993, federal, state, and local health agencies spent an estimated $\$ 14$. 4 billion on core public health functions, $1 \%-2 \%$ of the $\$ 903$ billion in total health-care expenditure (43).

\footnotetext{
${ }^{\dagger}$ A local health department is an administrative or service unit of local or state government responsible for the health of a jurisdiction smaller than the state.

$\S$ T $=$ P.L. 79-725
} 
Public Health System - Continued

\section{Conclusion}

The public health infrastructure changed to provide the elements necessary for successful public health interventions: organized and systematic observations through morbidity and mortality surveillance, well-designed epidemiologic studies and other data to facilitate the decision-making process, and individuals and organizations to advocate for resources and to ensure that effective policies and programs were implemented and conducted properly. In 1999, public health is a complex partnership among federal agencies, state and local governments, nongovernment organizations, academia, and community members. In the 21st century, the success of the U.S. public health system will depend on its ability to change to meet new threats to the public's health.

Reported by: Epidemiology Program Office, Office of the Director, CDC.

\section{References}

1. CDC. Ten great public health achievements-United States, 1900-1999. MMWR 1999;48:241-3.

2. CDC. Impact of vaccines universally recommended for children-United States, 1990-1998. MMWR 1999;48:243-8.

3. CDC. Motor-vehicle safety: a 20th century public health achievement. MMWR 1999;48:369-74.

4. CDC. Improvements in workplace safety-United States, 1900-1999. MMWR 1999;48:461-9.

5. CDC. Control of infectious diseases. MMWR 1999;48:621-9.

6. CDC. Decline in deaths from heart disease and stroke-United States, 1900-1999. MMWR 1999;48:649-56.

7. CDC. Healthier mothers and babies. MMWR 1999;48:849-57.

8. CDC. Safer and healthier foods. MMWR 1999;48:905-13.

9. CDC. Fluoridation of drinking water to prevent dental caries. MMWR 1999;48:933-40.

10. CDC. Tobacco use-United States, 1900-1999. MMWR 1999;48:986-93.

11. CDC. Family planning. MMWR 1999;48:1073-80.

12. Susser M. Epidemiology in the United States after World War Il: the evolution of technique. Epid Reviews 1985;7:147-77.

13. Turnock BJ. The organization of public health in the United States. In: Turnock BJ, ed. Public health: What it is and how it works. Gaithersburg, Maryland: Aspen Publication, 1997:1121-68.

14. Last JM. Scope and method of prevention. In: Last JM, Wallace RB, eds. Maxcy-Rosenau-Last Public health and preventive medicine. 13th ed. Norwalk, Connecticut: Appleton \& Lange, 1992:11-39.

15. Hanlon JJ, Pickett GE. Public health: administration and practice. 8th ed. St. Louis, Missouri: Times Mirror/Mosby College Publishing, 1984:22-44.

16. Koplan JP, Thacker SB, Lezin NA. Epidemiology in the 21st century: calculation, communication, and intervention. Am J Public Health 1999;89:1153-5.

17. Terris M. Evolution of public health and preventive medicine in the United States. Am J Public Health 1975;65:161-9.

18. Vandenbroucke JP. Clinical investigation in the 20th century: the ascendency of numerical reasoning. Lancet 1998;352(suppl 2):12-6.

19. Vandenbroucke JP. A short note on the history of the randomized controlled trial. J Chronic Dis 1987;40:985-6.

20. Doll R. Clinical trials: retrospect and prospect. Statistics in Medicine 1982;1:337-44.

21. Armitage $P$. The role of randomization in clinical trials. Statistics in Medicine 1982;1:345-52.

22. Doll R, Hill AB. Smoking and carcinoma of the lung. Br Med J 1950;2:740-8.

23. Teutsch SM, Churchill RE, eds. Principles and practice of public health surveillance. New York: Oxford University Press, 1994.

24. Remington PL, Smith MY, Williamson DF, Anda RF, Gentry EM, Hogelin GC. Design, characteristics and usefulness of state-based behavioral risk factor surveillance, 1981-87. Public Health Rep 1988;103:366-75.

25. Kann L, Kinchen SA, Williams BI, et al. Youth risk behavior surveillance-United States, 1997. In: CDC surveillance summaries (August 14). MMWR 47(no. SS-3). 
Public Health Infrastructure - Continued

26. Mosher WD. Design and operation of the 1995 national survey of family growth. Fam Plann Perspect 1998;43-6.

27. CDC. Summary of notifiable diseases, United States, 1997. MMWR 1997;46(no. SS-54).

28. Langmuir AD. The surveillance of communicable diseases of national importance. $\mathrm{N}$ Engl J Med 1963;268:182-92.

29. CDC. History perspectives: history of CDC. MMWR 1996;45:526-8.

30. Roemer MI. Preparing public health leaders for the 1990s. Public Health Rep 1988;103:443-51.

31. Winkelstein W, French FE. The training of epidemiologists in schools of public health in the United States: a historical note. Int J Epidemiol 1973;2:415-6.

32. Association of Schools of Public Health. Enrollment of U.S. schools of public health 1987-1997. Available at http://www.asph.org/webstud1.gif. Accessed December 14, 1999.

33. Crawford BL. Graduate students in U.S. schools of public health: comparison of 3 academic years. Public Health Rep 1979;94:67-72.

34. Association of Schools of Public Health. Ten most frequently asked questions by perspective students. Available at http://www.asph.org/10quest.htm. Accessed December 14, 1999.

35. US Treasury Department/Public Health Service. History of county health organizations in the United States 1908-1933. In: Public health bulletin (No. 222). Washington, DC: Public Health Service, 1936.

36. Altman D, Morgan DH. The role of state and local government in health. Health Affairs $1983 ; 2 ; 7-31$.

37. Mountin JW, Flook E. Guide to health organization in the United States, 1951. Washington, DC: Public Health Service, Federal Security Agency, Bureau of State Services, 1951; PHS publication no. 196.

38. Emerson H, Luginbuhl M. 1200 local public school departments for the United States. Am J Public Health 1945;35:898-904.

39. Dyal WW. Ten organizational practices of public health: a historical perspective. Am J Prev Med 1995;11(suppl 2):6-8.

40. Institute of Medicine. The future of public health. Washington, DC: National Academy Press, 1988.

41. Public Health Service. Healthy people 2000: national health promotion and disease prevention objectives-full report, with commentary. Washington, DC: US Department of Health and Human Services, Public Health Service, 1991; DHHS publication no. (PHS)91-50212.

42. CDC. Selected characteristics of local health departments-United States, 1992-1993. MMWR 1994;43:839-43.

43. CDC. Estimated expenditures for core public health functions-selected states, October 1992September 1993. MMWR 1995;44:421,427-9.

\section{Community Needs Assessment and Morbidity Surveillance Following an Earthquake - Turkey, August 1999}

On August 17, 1999, at 3:01 a.m., an earthquake registering 7.4 on the Richter scale, with an epicenter on the northern strand of the North Anatolian fault near the town of Gölcük, struck western Turkey. The earthquake resulted in an estimated 17,000 deaths and 10,000 missing persons. An additional 24,000 persons were injured, and approximately 600,000 were left homeless. Numerous aftershocks occurred during the following month, causing further damage and loss. To provide an objective postdisaster measure of needs to decision makers in the affected area, at the request of Turkey's Marmara University Department of Public Health, CDC conducted a community needs assessment in one camp and a study of clinic visits in two camps 2 and 6 weeks after the earthquake. This report summarizes the results of the assessment and studies, which indicate that housing and winter clothing were the primary needs in the camp 
Earthquake - Continued

and upper respiratory ailments, depression, and musculoskeletal pain were the predominant illnesses.

CDC conducted the needs assessment in the Bahcecik camp that local authorities established 1 week after the earthquake in the Gölcük region, possibly the area most affected by the disaster. In collaboration with Marmara University Department of Public Health, local health authorities initiated health-care services for the camp, which had 248 tents. On October 1 and 2, CDC conducted a household survey using a systematic, random sample of a targeted 155 households. A household was defined as a unit of persons residing in one tent. One adult was interviewed from each selected household using a standardized questionnaire that focused on demographics, illnesses, injuries, sanitation, shelter, and medical needs.

Morbidity surveillance data were characterized during the subacute, post-earthquake phase at the Bahcecik camp clinic and the Izmir camp clinic in the Gölcük area. CDC reviewed logbook entries for two 8-day periods, from August 30 (the first day for which clinic records were available at both sites) through September 6 and from September 25 through October 2. For the first 8-day period, 468 and 534 logbook entries at the Bahcecik and Izmir camp clinics, respectively, were reviewed; for the second 8-day period, 411 and 669 logbook entries, respectively, were reviewed.

In Bahcecik, 154 households were visited, and 86 (56\%) interviews were completed. The survey represented 339 persons (median household size: four persons). Of the 86 households, seven $(8 \%)$ had a child aged $\leq 2$ years, nine $(10 \%)$ had a household member aged $\geq 65$ years, and three households ( $4 \%$ ) reported a pregnant female. Fiftyfour $(63 \%)$ reported that their homes were damaged and uninhabitable, and $22(26 \%)$ reported their homes were destroyed completely.

The Bahcecik clinic provided medical care for persons in 85 (99\%) of the surveyed households. Of the 86 households, one (1\%) reported an earthquake-related death.* Members of $20(23 \%)$ households sustained injuries, and lacerations accounted for $90 \%$ of the injuries. Sixty-nine households (80\%) reported having at least one ill household member since the earthquake, representing 128 ill persons. Approximately $32(25 \%)$ persons reported depression; $14(44 \%)$ of those sought medical treatment. Twenty-four (19\%) persons reported respiratory illness; 23 (96\%) of those requested medical treatment. Twenty (17\%) noted chronic diseases, specifically kidney problems, hypertension, and heart disease; $16(80 \%)$ of those sought medical treatment. Thirteen (10\%) experienced gastrointestinal illness; $11(86 \%)$ of those sought medical treatment.

The availability of food, water, and sanitation was well maintained after the earthquake. Respondents from 75 (87\%) of the 86 households reported that food was available and was provided mainly by the relief workers in the camp. Eighty-one (94\%) households reported piped water as the major source of drinking water. Eighty-three $(97 \%)$ households had access to showers. Most households (83 [97\%]) reported using field latrines connected to septic tanks for human waste disposal, and 45 (52\%) households reported the latrines as "clean" or "somewhat clean." In 77 (90\%) households, members had access to transportation, and $83(97 \%)$ households had garbage disposal by municipal collection. Electricity was not available for $79(92 \%)$ households.

\footnotetext{
*This low percentage probably reflects that Turkish families generally live together in one household and that entire families either died or survived. It does not reflect friends, co-workers, and possible extended family members who were killed.
} 


\section{Earthquake - Continued}

Logbook entries at Bahcecik camp clinic and Izmir camp clinic from August 30 through September 6 and September 25 through October 2 indicated that most visits were for illnesses rather than injuries (Table 1). The primary illnesses reported during the 8-day periods in both camps were upper respiratory tract infection, followed by musculoskeletal pain. All other illnesses, including diarrhea, represented no more than $10 \%$ of the total visits (Tables 2 and 3 ).

Reported by: J Jennings, PhD, Conscience International, Inc., Atlanta, Georgia. H Harmanci, MD, T Erbaydar, MD, Marmara Univ Dept of Public Health; S Erbaydar, MD, N Yolsal, MD, Istanbul Medical Faculty, Dept of Public Health, Istanbul, Turkey. Environmental Hazards Epidemiology Section, Health Studies Br, Div of Environmental Hazards and Health Effects, National Center for Environmental Health; Div of Applied Public Health Training, Epidemiology Program Office; and an EIS Officer, CDC.

Editorial Note: An earthquake of great magnitude is one of the most devastating events in nature. In Turkey, infrastructure damage and losses were an estimated \$6.5 billion. In the Bahcecik camp, where $88 \%$ of the camp's population is homeless, the primary need is housing. Most inhabitants will remain in tents until they receive prefabricated houses. In addition, the low frequency of gastrointestinal diseases suggests that sanitary conditions at the camp are well maintained. Although 73 (85\%) households indicated access to a medication source and direct observation showed a wellstocked medication supply area, the most common medications needed for diabetes, hypertension, depression, and analgesics and vitamins were not available according to those interviewed.

Following the assessment and studies, results were reported to the local health authorities of Turkey and the nongovernment organization. Recommendations included providing shelter, heat, and clothing suitable for winter conditions; providing

TABLE 1. Number and percentage of illnesses and injuries reported at Bahcecik camp and Izmir camp clinics - Turkey, 1999

\begin{tabular}{llcllll}
\hline & \multicolumn{2}{c}{ IIInesses } & & \multicolumn{2}{c}{ Injuries } & \\
\cline { 2 - 3 } Camp & No. & (\%) & & No. & (\%) & Total \\
\hline Bahcecik & & & & & \\
$\quad$ Aug. 30-Sept. 6 & 434 & $(92.7)$ & & 34 & $(7.3)$ & $\mathbf{4 6 8}$ \\
$\quad$ Sept. 25-Oct. 2 & 382 & $(92.9)$ & & 29 & $(7.1)$ & $\mathbf{4 1 1}$ \\
Izmir & & & & & \\
$\quad$ Aug. 30-Sept. 6 & 492 & $(92.1)$ & & 42 & $(7.9)$ & $\mathbf{5 3 4}$ \\
Sept. 25-Oct. 2 & 628 & $(93.9)$ & 41 & $(6.1)$ & $\mathbf{6 6 9}$ \\
\hline
\end{tabular}

TABLE 2. Number and percentage of illnesses reported at Bahcecik clinic 2 and 6 weeks after earthquake, by diagnosis and week - Turkey, 1999

\begin{tabular}{lrr|lrc}
\hline \multicolumn{2}{c|}{ Bahcecik week 2 } & & \multicolumn{3}{c}{ Bahcecik week 6 } \\
\hline Diagnosis & No. & $(\%)$ & Diagnosis & No. & (\%) \\
\hline Upper respiratory tract & & & Upper respiratory tract & & \\
infection & 116 & $(24.8)$ & infection & 125 & $(24.8)$ \\
Musculoskeletal pain & 32 & $(6.8)$ & Musculoskeletal pain & 25 & $(6.0)$ \\
Watery diarrhea & 28 & $(6.0)$ & Skin infection & 17 & $(4.1)$ \\
Psychiatric illness & 27 & $(5.8)$ & Dental/Oral disease & 16 & $(3.9)$ \\
Hypertension & 21 & $(4.5)$ & Hypertension & 14 & $(3.3)$ \\
\hline
\end{tabular}


Earthquake - Continued

TABLE 3. Number and percentage of illnesses reported at Izmir clinic 2 and 6 weeks after earthquake, by diagnosis and week - Turkey, 1999

\begin{tabular}{|c|c|c|c|c|c|}
\hline \multicolumn{3}{|c|}{ Izmir week 2} & \multicolumn{3}{|c|}{ Izmir week 6} \\
\hline Diagnosis & No. & (\%) & Diagnosis & No. & (\%) \\
\hline $\begin{array}{l}\text { Upper respiratory tract } \\
\text { infection }\end{array}$ & 126 & $(20.0)$ & $\begin{array}{l}\text { Upper respiratory tract } \\
\text { infection }\end{array}$ & 168 & $(21.8)$ \\
\hline Musculoskeletal & 61 & $(9.6)$ & Musculoskeletal & 52 & ( 6.8$)$ \\
\hline Skin rash & 41 & (6.5) & Skin infection & 24 & (3.1) \\
\hline Hypertension & 40 & $(6.3)$ & Dyspepsia & 21 & ( 2.7) \\
\hline $\begin{array}{l}\text { Lower respiratory tract } \\
\text { infection }\end{array}$ & 35 & $(5.5)$ & $\begin{array}{l}\text { Lower respiratory tract } \\
\text { infection }\end{array}$ & 21 & ( 2.7) \\
\hline
\end{tabular}

mental health-care services, social activities, and community jobs to address community stress; continuing the level of medical care; and encouraging reporting of morbidity data from local camp clinics to regional health offices.

Rapid needs assessment of an affected population is an important initial step of response in a disaster and can minimize inappropriateness of relief in terms of delays and content (1). In addition, information from emergency medical surveillance may control the rumors of epidemics and help local health authorities of Turkey focus on allocating resources to address identified needs to reduce overcrowding and provide counseling.

Reference

1. Guha-Sapir D. Rapid assessment of health needs in mass emergencies: review of current concepts and method. World Health Stat Q 1991;44:171-81.

\section{Imported Dengue — Florida, 1997-1998}

Dengue fever is a viral disease transmitted primarily by the Aedes aegypti mosquito. There are four antigenically distinct serotypes of dengue virus (DEN-1, DEN-2, DEN-3 and DEN-4). Infection with any serotype may lead to an acute illness characterized by fever, headache, bone and joint pain and, occasionally, rash and hemorrhagic manifestations (1). Secondary infection with a different serotype can lead to a more serious form of the disease (i.e., dengue hemorrhagic fever [DHF]). Dengue incidence has recently increased in the Caribbean and Central America (2), including Cuba and the Bahamas, which are within 100 miles of Florida, and might increase the likelihood of its future autochthonous transmission in Florida. This report summarizes information about cases of imported dengue detected as a result of a laboratorybased active surveillance program implemented in Florida from April 1, 1997, through March 31, 1998.

Dengue surveillance program elements included implementation of an education program focusing on county health departments and commercial clinical laboratories, and enhancing the state laboratory's diagnostic capabilities. Dengue information packets were mailed to all 67 county health department epidemiologists in Florida. Packets contained a letter explaining the program and requesting participation, along with instructions for distributing the enclosed materials to hospital emergency departments, clinics, health departments, and infectious disease physicians within the 
Imported Dengue - Continued

county. The letter included a reminder that dengue is a reportable disease in Florida and that testing would be performed free of charge. The dengue case definition, specimen requirements and transport instructions, and a dengue case investigation form were supplied.

Cooperative agreements were made with commercial clinical laboratories to promote submission of dengue samples. Under the agreements, specimens from suspected dengue cases were forwarded to the state laboratory for testing. In cases where specimens were tested at commercial laboratories only, dengue antibody positive results were forwarded to county health departments and then to the state laboratory for inclusion in this study.

State laboratory capabilities were enhanced to include testing for anti-dengue $\lg M$ antibodies. Acute and convalescent serum specimens were tested for dengue antibodies using the hemagglutination inhibition assay and $\lg M$ antibody capture enzyme linked immunosorbent assay (3,4). Specimens positive for IgM antibodies were forwarded to the Dengue Branch, CDC, in San Juan, Puerto Rico, for confirmation of serologic results, and acute phase samples were forwarded to CDC for virus isolation or identification by polymerase chain reaction (PCR) $(5,6)$.

During the 12 months of active surveillance, 83 suspected dengue cases were investigated in Florida. Commercial clinical laboratories referred specimens from $36(43 \%)$ of these cases. The remaining specimens were referred through county health departments, hospital laboratories, infection-control practitioners, or directly from physicians. Recent dengue infection was laboratory-diagnosed in $18(22 \%)$ of these cases. Thirteen (72\%) of the 18 positive dengue specimens were referred to the study by commercial laboratories. All four dengue serotypes were detected (by virus isolation and/or identification by PCR) in five of the cases studied. Dengue was ruled out as the etiologic agent in $24(29 \%)$ cases. The remaining $41(49 \%)$ cases were indeterminate because of a lack of convalescent serum samples.

The age of laboratory-confirmed case-patients ranged from 8 to 69 years (median: 38 years), and 14 (78\%) were male. Antibody titers were suggestive of secondary dengue infection in $10(56 \%)$ of the 18 cases. Two (11\%) appeared to be primary infections, and laboratory tests necessary to determine infection status (primary versus secondary) were not available in the other six cases. Hemorrhagic manifestations were reported in seven (39\%) of the laboratory-confirmed cases, one of which met the case criteria for DHF.

All case-patients reported recent (i.e., within 10 days before onset of illness) travel from countries with indigenous dengue transmission, and no local transmission was detected in Florida. The origin of travel of case-patients was Haiti (six), Puerto Rico (three), Colombia (two), Venezuela (two), Barbados (one), Nicaragua (one), and Thailand (one). The two other case-patients did not indicate a specific travel destination but reportedly had visited countries where dengue occurs. Dengue cases were detected in Dade (eight), Hillsborough (four), Orange (three), Palm Beach (two), and Broward (one) counties.

Reported by: J Gill, PhD, LM Stark, PhD, S Wiersma, MD, Bur of Laboratories and Epidemiology, Florida Dept of Health. Dengue Br, Div of Vector-Borne Infectious Diseases, National Center for Infectious Diseases, CDC.

Editorial note: Local transmission of dengue was last documented in Florida in 1934 (7). Although no local transmission of dengue was detected in Florida during this 
Imported Dengue - Continued

investigation, many southern states may be at risk for transmission; dengue transmission has been detected in Texas (8). Two mosquito vectors (Aedes aegypti and Ae albopictus ) are widely distributed in Florida, and many infected travelers return from areas where dengue is endemic and the resident population has essentially no immunity to dengue viruses.

Autochthonous transmission may result from importation of viremic cases to counties with Ae aegypti or Ae albopictus. This possibility should especially be considered if cases are reported from such localities over several years and if case-patients from these localities report travel to a country where dengue is endemic. Epi- demiologic data from imported cases should be shared on a timely basis with mosquito abatement programs to ensure an entomologic evaluation and appropriate control response by the locality where the case-patients reside. On the basis of the results of this study, surveillance efforts should be concentrated in counties with large populations and large numbers of international travelers and should intensify during dengue season (i.e., July-November) in the Caribbean because of the large number of casepatients who travel to this area.

The findings in this report indicate that dengue infections were imported into Florida in 1997 and 1998 more frequently than expected, based on the 10-year mean of 1.3 cases per year. In this and previous investigations, dengue has been underreported $(9,10)$. Underreporting is common with passive surveillance systems. Active surveillance for dengue requires that state health departments educate the medical community and provide appropriate diagnostic laboratory support (8). Surveillance efforts should be enhanced in the high-risk areas identified in this study. Other states should consider enhanced dengue surveillance in areas with widespread mosquito vectors and large numbers of travelers returning from areas with endemic dengue.

\section{References}

1. Hayes EB, Gubler D. Dengue and dengue hemorrhagic fever. Pediatr Infect Dis J 1992;11:311-7.

2. Pan American Health Organization. Re-emergence of dengue in the Americas. Epidemiological Bulletin, PAHO 1997;18:1-10.

3. Clarke $\mathrm{DH}$, Casals J. Techniques for hemagglutination and hemagglutination-inhibition with arthropod-borne viruses. Am J Trop Med Hyg 1958;7:561-77.

4. Innis BL, Nisalak A, Nimmannitya S, et al. An enzyme-linked immunosorbent assay to characterize dengue infections where dengue and Japanese encephalitis co-circulate. Am J Trop Med Hyg 1989;40:418-27.

5. Gubler DJ, Kuno G, Sather GE, Vélez M, Oliver A. Mosquito cell cultures and specific monoclonal antibodies in surveillance for dengue viruses. Am J Trop Med Hyg 1984;33:158-65.

6. Lanciotti RS, Calisher CH, Gubler DJ, Chang GJ, Vorndam AV. Rapid detection and typing of dengue viruses from clinical samples by using reverse transcriptase-polymerase chain reaction. J Clin Microbiol 1992;30:545-51.

7. Ehrenkranz NJ, Ventura AK, Cuadrado RR, Pond WL, Porter JE. Pandemic dengue in Caribbean countries and the southern United States-past, present and potential problems. N Engl J Med 1971;285:1460-9.

8. Rawlings RA, Hendricks KA, Burgess CR, et al. Dengue surveillance in Texas, 1995. Am J Trop Med Hyg 1998;59:95-9.

9. Karp BE. Dengue fever: a risk to travelers. Maryland Med J 1997;46:299-302.

10. Lyerla R, Rigau-Pérez JG, Vorndam AV, et al. A dengue outbreak among camp participants in a Caribbean island, 1995. J Travel Med 1999 (in press). 
Notice to Readers - Continued

Notice to Readers

\section{Epi Info 2000:}

\section{A Course for Teachers and Practitioners of Epidemiologic Computing}

CDC and Emory University's Rollins School of Public Health will cosponsor a course, “Epi Info 2000: A Course for Practitioners and Teachers of Epidemiologic Computing" on March 13-17, 2000, in Atlanta. The course is designed for practitioners or teachers of epidemiologic computing with intermediate to advanced skills in computing.

The course covers hands-on experience with the new Windows ${ }^{\circledR}$ version of Epi Info, programming Epi Info software at the intermediate to advanced level, methods of teaching epidemiologic computing, and computerized interactive exercises for teaching epidemiology and computing. There is a tuition charge.

Additional information and applications are available from Emory University, The Rollins School of Public Health, International Health Dept (PIA), 1518 Clifton Rd., N.E., Room 746, Atlanta, GA 30322; telephone (404) 727-3485; fax (404) 727-4590; e-mail pvaleri@sph.emory.edu.

\section{Notice to Readers}

\section{Combined Issues of MMWR}

A December 31, 1999, issue of MMWR will not be published. The next issue will be Volume 48, Numbers 51 and 52, dated January 7, 2000. It will include the figures and tables of notifiable diseases and deaths for the weeks ending December 25, 1999, and January 1, 2000. 
FIGURE I. Selected notifiable disease reports, comparison of provisional 4-week totals ending December 18, 1999, with historical data - United States

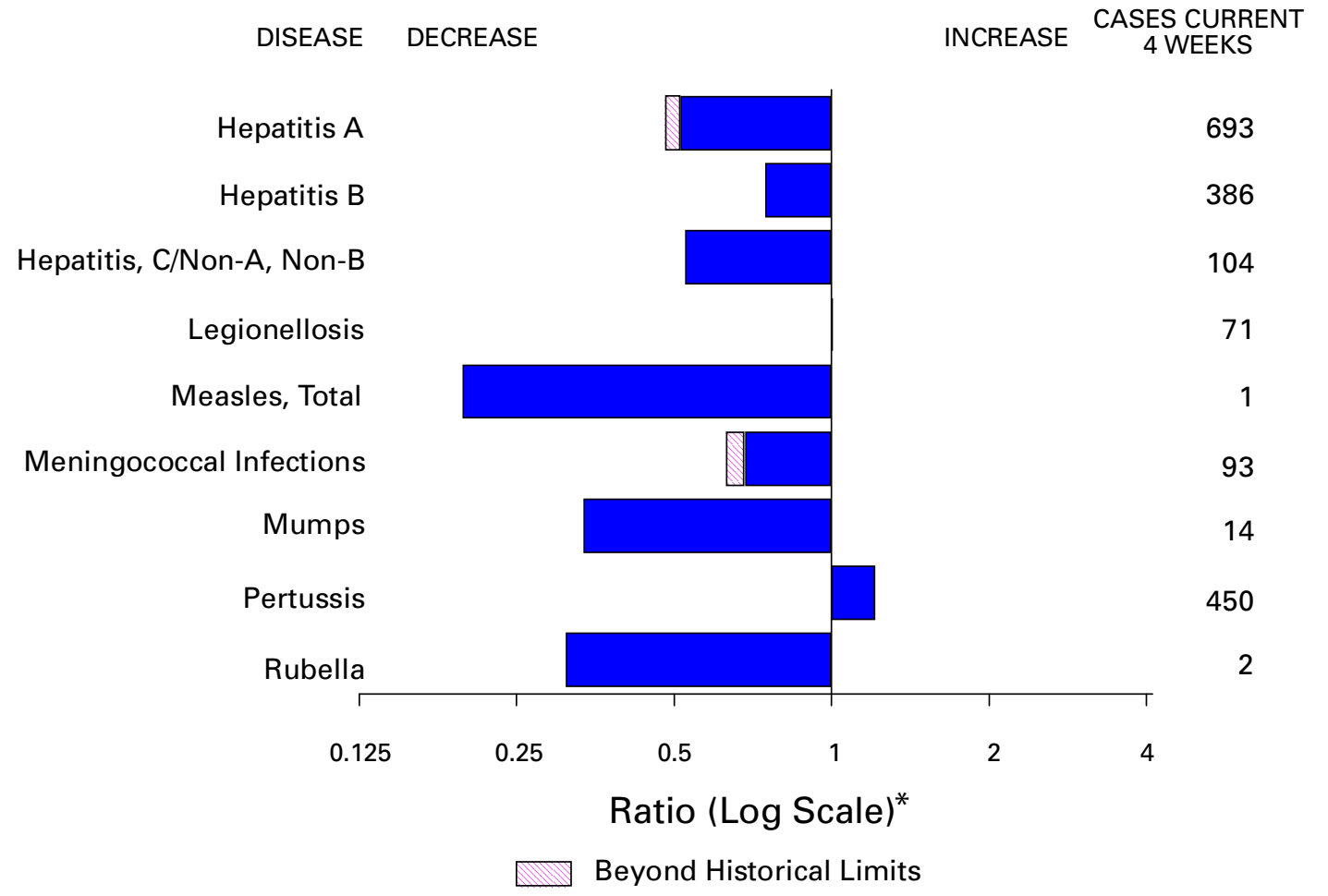

* Ratio of current 4-week total to mean of 15 4-week totals (from previous, comparable, and subsequent 4-week periods for the past 5 years). The point where the hatched area begins is based on the mean and two standard deviations of these 4-week totals.

TABLE I. Summary — provisional cases of selected notifiable diseases, United States, cumulative, week ending December 18, 1999 (50th Week)

\begin{tabular}{|c|c|c|c|c|}
\hline & Cum. 1999 & & Cum. 1999 \\
\hline \multicolumn{2}{|l|}{ Anthrax } & - & HIV infection, pediatric ${ }^{* \S}$ & 137 \\
\hline \multicolumn{2}{|l|}{ Brucellosis* } & 47 & Plague & 8 \\
\hline \multicolumn{2}{|c|}{ Cholera } & 3 & Poliomyelitis, paralytic & - \\
\hline \multirow{2}{*}{\multicolumn{2}{|c|}{$\begin{array}{l}\text { Congenital rubella syndrome } \\
\text { Cyclosporiasis* }\end{array}$}} & 6 & Psittacosis* & 16 \\
\hline & $s^{*}$ & 51 & Rabies, human & - \\
\hline \multicolumn{2}{|c|}{ Diphtheria } & 1 & Rocky Mountain spotted fever (RMSF) & 540 \\
\hline \multirow[t]{4}{*}{ Encephalitis: } & California* & 60 & Streptococcal disease, invasive Group A & 2,048 \\
\hline & eastern equine ${ }^{*}$ & 6 & Streptococcal toxic-shock syndrome* & 36 \\
\hline & St. Louis* & 6 & Syphilis, congenital & 237 \\
\hline & western equine ${ }^{*}$ & 1 & Tetanus & 32 \\
\hline Ehrlichiosis & human granulocytic (HGE)* & 150 & Toxic-shock syndrome & 113 \\
\hline & human monocytic (HME)* & 40 & Trichinosis & 9 \\
\hline${ }_{\text {Hansen Disease }}^{\text {numan monocytic (HIVIE) }}$ & $\mathrm{se}^{*}$ & 95 & Typhoid fever & 297 \\
\hline \multicolumn{2}{|c|}{ Hantavirus pulmonary syndrome ${ }^{* \dagger}$} & 21 & Yellow fever & 1 \\
\hline \multicolumn{2}{|c|}{ Hemolytic uremic syndrome, post-diarrheal* } & 117 & & \\
\hline
\end{tabular}

-:no reported cases

* Not notifiable in all states.

$\dagger$ Updated weekly from reports to the Division of Viral and Rickettsial Diseases, National Center for Infectious Diseases (NCID).

$\S$ Updated monthly from reports to the Division of HIV/AIDS Prevention-Surveillance and Epidemiology, National Center for

HIV, STD, and TB Prevention (NCHSTP), last update November 28, 1999.

I Updated from reports to the Division of STD Prevention, NCHSTP. 
TABLE II. Provisional cases of selected notifiable diseases, United States, weeks ending December 18, 1999, and December 19, 1998 (50th Week)

\begin{tabular}{|c|c|c|c|c|c|c|c|c|c|c|}
\hline \multirow[b]{3}{*}{ Reporting Area } & \multirow{2}{*}{\multicolumn{2}{|c|}{ AIDS }} & \multirow{2}{*}{\multicolumn{2}{|c|}{ Chlamydia }} & \multirow{2}{*}{\multicolumn{2}{|c|}{ Cryptosporidiosis }} & \multicolumn{4}{|c|}{$\begin{array}{c}\text { Escherichia } \\
\text { coli 0157:H7* }\end{array}$} \\
\hline & & & & & & & & & & \\
\hline & $\begin{array}{l}\text { Cum. } \\
\text { 1999 }^{\dagger}\end{array}$ & $\begin{array}{l}\text { Cum. } \\
1998\end{array}$ & $\begin{array}{l}\text { Cum. } \\
1999\end{array}$ & $\begin{array}{l}\text { Cum. } \\
1998\end{array}$ & $\begin{array}{l}\text { Cum. } \\
1999\end{array}$ & $\begin{array}{l}\text { Cum. } \\
1998\end{array}$ & $\begin{array}{l}\text { Cum. } \\
1999\end{array}$ & $\begin{array}{l}\text { Cum. } \\
1998\end{array}$ & $\begin{array}{l}\text { Cum. } \\
1999\end{array}$ & $\begin{array}{l}\text { Cum } \\
1998\end{array}$ \\
\hline UNITED STATES & 40,933 & 43,859 & 576,331 & 573,378 & 2,292 & 3,592 & 3,375 & 2,862 & 2,308 & 2,147 \\
\hline $\begin{array}{l}\text { NEW ENGLAND } \\
\text { Maine } \\
\text { N.H. } \\
\text { Vt. } \\
\text { Mass. } \\
\text { R.I. } \\
\text { Conn. }\end{array}$ & $\begin{array}{r}2,090 \\
75 \\
45 \\
16 \\
1,338 \\
96 \\
520\end{array}$ & $\begin{array}{r}1,728 \\
28 \\
36 \\
18 \\
906 \\
119 \\
621\end{array}$ & $\begin{array}{r}28,927 \\
904 \\
925 \\
453 \\
17,427 \\
2,251 \\
6,967\end{array}$ & $\begin{array}{r}19,436 \\
1,001 \\
934 \\
398 \\
8,081 \\
2,226 \\
6,796\end{array}$ & $\begin{array}{r}159 \\
30 \\
19 \\
36 \\
53 \\
6 \\
15\end{array}$ & $\begin{array}{r}148 \\
31 \\
16 \\
26 \\
68 \\
7 \\
U\end{array}$ & $\begin{array}{r}396 \\
39 \\
34 \\
32 \\
172 \\
27 \\
92\end{array}$ & $\begin{array}{r}329 \\
36 \\
46 \\
21 \\
146 \\
13 \\
67\end{array}$ & $\begin{array}{r}343 \\
- \\
33 \\
21 \\
184 \\
26 \\
79\end{array}$ & $\begin{array}{r}279 \\
-\overline{4} \\
18 \\
157 \\
1 \\
56\end{array}$ \\
\hline $\begin{array}{l}\text { MID. ATLANTIC } \\
\text { Upstate N.Y. } \\
\text { N.Y. City } \\
\text { N.J. } \\
\text { Pa. }\end{array}$ & $\begin{array}{r}10,473 \\
1,196 \\
5,571 \\
1,932 \\
1,774\end{array}$ & $\begin{array}{r}11,961 \\
1,434 \\
6,850 \\
2,014 \\
1,663\end{array}$ & $\begin{array}{r}56,003 \\
\mathrm{~N} \\
21,963 \\
10,095 \\
23,945\end{array}$ & $\begin{array}{r}59,556 \\
N \\
25,226 \\
11,356 \\
22,974\end{array}$ & $\begin{array}{r}418 \\
176 \\
116 \\
36 \\
90\end{array}$ & $\begin{array}{r}561 \\
330 \\
206 \\
25 \\
\mathrm{~N}\end{array}$ & $\begin{array}{r}315 \\
253 \\
11 \\
51 \\
\mathrm{~N}\end{array}$ & $\begin{array}{r}296 \\
215 \\
14 \\
67 \\
\mathrm{~N}\end{array}$ & $\begin{array}{r}92 \\
- \\
17 \\
46 \\
29\end{array}$ & $\begin{array}{r}86 \\
- \\
13 \\
52 \\
21\end{array}$ \\
\hline $\begin{array}{l}\text { E.N. CENTRAL } \\
\text { Ohio } \\
\text { Ind. } \\
\text { III. } \\
\text { Mich. } \\
\text { Wis. }\end{array}$ & $\begin{array}{r}2,801 \\
448 \\
320 \\
1,345 \\
555 \\
133\end{array}$ & $\begin{array}{r}3,185 \\
645 \\
485 \\
1,188 \\
680 \\
187\end{array}$ & $\begin{array}{r}82,868 \\
26,294 \\
10,930 \\
25,133 \\
20,511 \\
U\end{array}$ & $\begin{array}{l}97,431 \\
26,622 \\
10,838 \\
25,660 \\
20,785 \\
13,526\end{array}$ & $\begin{array}{r}567 \\
66 \\
40 \\
67 \\
49 \\
345\end{array}$ & $\begin{array}{r}725 \\
73 \\
61 \\
84 \\
38 \\
469\end{array}$ & $\begin{array}{r}703 \\
253 \\
114 \\
221 \\
115 \\
\mathrm{~N}\end{array}$ & $\begin{array}{r}454 \\
126 \\
102 \\
111 \\
115 \\
\mathrm{~N}\end{array}$ & $\begin{array}{r}497 \\
208 \\
64 \\
81 \\
78 \\
66\end{array}$ & $\begin{array}{r}370 \\
77 \\
54 \\
80 \\
71 \\
88\end{array}$ \\
\hline $\begin{array}{l}\text { W.N. CENTRAL } \\
\text { Minn. } \\
\text { lowa } \\
\text { Mo. } \\
\text { N. Dak. } \\
\text { S. Dak. } \\
\text { Nebr. } \\
\text { Kans. }\end{array}$ & $\begin{array}{r}940 \\
178 \\
77 \\
449 \\
6 \\
15 \\
65 \\
150\end{array}$ & $\begin{array}{r}840 \\
163 \\
68 \\
400 \\
5 \\
15 \\
66 \\
123\end{array}$ & $\begin{array}{r}33,533 \\
6,683 \\
4,649 \\
12,427 \\
707 \\
1,522 \\
3,319 \\
4,226\end{array}$ & $\begin{array}{r}33,858 \\
6,787 \\
4,356 \\
12,151 \\
998 \\
1,509 \\
2,694 \\
5,363\end{array}$ & $\begin{array}{r}204 \\
78 \\
55 \\
29 \\
18 \\
7 \\
16 \\
1\end{array}$ & $\begin{array}{r}335 \\
142 \\
65 \\
27 \\
30 \\
25 \\
35 \\
11\end{array}$ & $\begin{array}{r}606 \\
234 \\
114 \\
60 \\
17 \\
47 \\
113 \\
21\end{array}$ & $\begin{array}{r}475 \\
196 \\
91 \\
53 \\
12 \\
35 \\
52 \\
36\end{array}$ & $\begin{array}{r}414 \\
184 \\
73 \\
66 \\
14 \\
62 \\
- \\
15\end{array}$ & $\begin{array}{r}403 \\
211 \\
59 \\
64 \\
15 \\
40 \\
- \\
14\end{array}$ \\
\hline $\begin{array}{l}\text { S. ATLANTIC } \\
\text { Del. } \\
\text { Md. } \\
\text { D.C. } \\
\text { Va. } \\
\text { W. Va. } \\
\text { N.C. } \\
\text { S.C. } \\
\text { Ga. } \\
\text { Fla. }\end{array}$ & $\begin{array}{r}11,305 \\
159 \\
1,344 \\
637 \\
782 \\
64 \\
739 \\
919 \\
1,581 \\
5,080\end{array}$ & $\begin{array}{r}11,374 \\
152 \\
1,607 \\
808 \\
908 \\
77 \\
753 \\
720 \\
1,173 \\
5,176\end{array}$ & $\begin{array}{r}121,497 \\
2,674 \\
10,838 \\
\mathrm{~N} \\
13,391 \\
1,240 \\
20,705 \\
12,830 \\
31,191 \\
28,628\end{array}$ & $\begin{array}{r}111,069 \\
2,493 \\
7,201 \\
N \\
13,376 \\
2,306 \\
21,209 \\
17,493 \\
22,989 \\
24,002\end{array}$ & $\begin{array}{r}379 \\
17 \\
8 \\
27 \\
3 \\
33 \\
- \\
136 \\
155\end{array}$ & $\begin{array}{r}343 \\
3 \\
19 \\
25 \\
20 \\
2 \\
\mathrm{~N} \\
- \\
127 \\
147\end{array}$ & $\begin{array}{r}346 \\
6 \\
42 \\
1 \\
75 \\
14 \\
74 \\
21 \\
37 \\
76\end{array}$ & $\begin{array}{r}248 \\
- \\
43 \\
1 \\
N \\
13 \\
56 \\
15 \\
76 \\
44\end{array}$ & $\begin{array}{r}180 \\
3 \\
4 \\
U \\
59 \\
11 \\
52 \\
14 \\
- \\
37\end{array}$ & $\begin{array}{r}179 \\
2 \\
15 \\
U \\
55 \\
10 \\
47 \\
12 \\
- \\
38\end{array}$ \\
\hline $\begin{array}{l}\text { E.S. CENTRAL } \\
\text { Ky. } \\
\text { Tenn. } \\
\text { Ala. } \\
\text { Miss. }\end{array}$ & $\begin{array}{r}1,796 \\
255 \\
706 \\
449 \\
386\end{array}$ & $\begin{array}{r}1,820 \\
263 \\
658 \\
484 \\
415\end{array}$ & $\begin{array}{r}44,139 \\
7,014 \\
13,856 \\
12,314 \\
10,955\end{array}$ & $\begin{array}{r}40,018 \\
6,083 \\
13,621 \\
10,007 \\
10,307\end{array}$ & $\begin{array}{r}42 \\
8 \\
11 \\
14 \\
9\end{array}$ & $\begin{array}{r}26 \\
10 \\
10 \\
\mathrm{~N} \\
6\end{array}$ & $\begin{array}{r}133 \\
47 \\
54 \\
26 \\
6\end{array}$ & $\begin{array}{r}120 \\
36 \\
54 \\
24 \\
6\end{array}$ & $\begin{array}{r}58 \\
- \\
38 \\
16 \\
4\end{array}$ & $\begin{array}{r}64 \\
- \\
40 \\
20 \\
4\end{array}$ \\
\hline $\begin{array}{l}\text { W.S. CENTRAL } \\
\text { Ark. } \\
\text { La. } \\
\text { Okla. } \\
\text { Tex. }\end{array}$ & $\begin{array}{r}4,177 \\
188 \\
813 \\
123 \\
3,053\end{array}$ & $\begin{array}{r}5,350 \\
203 \\
914 \\
282 \\
3,951\end{array}$ & $\begin{array}{r}81,555 \\
5,585 \\
11,220 \\
7,763 \\
56,987\end{array}$ & $\begin{array}{r}86,314 \\
3,941 \\
14,689 \\
9,021 \\
58,663\end{array}$ & $\begin{array}{r}84 \\
2 \\
22 \\
12 \\
48\end{array}$ & $\begin{array}{r}914 \\
6 \\
16 \\
N \\
892\end{array}$ & $\begin{array}{r}128 \\
15 \\
9 \\
31 \\
73\end{array}$ & $\begin{array}{r}103 \\
11 \\
5 \\
25 \\
62\end{array}$ & $\begin{array}{r}124 \\
8 \\
14 \\
27 \\
75\end{array}$ & $\begin{array}{r}107 \\
10 \\
7 \\
9 \\
81\end{array}$ \\
\hline $\begin{array}{l}\text { MOUNTAIN } \\
\text { Mont. } \\
\text { Idaho } \\
\text { Wyo. } \\
\text { Colo. } \\
\text { N. Mex. } \\
\text { Ariz. } \\
\text { Utah } \\
\text { Nev. }\end{array}$ & $\begin{array}{r}1,608 \\
13 \\
22 \\
11 \\
290 \\
82 \\
819 \\
142 \\
229\end{array}$ & $\begin{array}{r}1,506 \\
29 \\
32 \\
5 \\
286 \\
203 \\
588 \\
128 \\
235\end{array}$ & $\begin{array}{r}29,988 \\
1,496 \\
1,670 \\
759 \\
5,417 \\
3,916 \\
11,863 \\
2,085 \\
2,782\end{array}$ & $\begin{array}{r}32,694 \\
1,277 \\
1,941 \\
690 \\
8,395 \\
3,959 \\
11,105 \\
2,091 \\
3,236\end{array}$ & $\begin{array}{r}99 \\
13 \\
8 \\
1 \\
14 \\
42 \\
13 \\
\mathrm{~N} \\
8\end{array}$ & $\begin{array}{r}122 \\
10 \\
17 \\
2 \\
19 \\
47 \\
18 \\
\mathrm{~N} \\
9\end{array}$ & $\begin{array}{r}324 \\
25 \\
68 \\
16 \\
107 \\
13 \\
37 \\
38 \\
20\end{array}$ & $\begin{array}{r}363 \\
16 \\
43 \\
53 \\
90 \\
19 \\
43 \\
75 \\
24\end{array}$ & $\begin{array}{r}225 \\
- \\
43 \\
14 \\
88 \\
7 \\
23 \\
48 \\
2\end{array}$ & $\begin{array}{r}247 \\
5 \\
25 \\
55 \\
69 \\
20 \\
27 \\
22 \\
24\end{array}$ \\
\hline $\begin{array}{l}\text { PACIFIC } \\
\text { Wash. } \\
\text { Oreg. } \\
\text { Calif. } \\
\text { Alaska } \\
\text { Hawaii }\end{array}$ & $\begin{array}{r}5,743 \\
337 \\
208 \\
5,089 \\
15 \\
94\end{array}$ & $\begin{array}{r}6,095 \\
386 \\
166 \\
5,365 \\
17 \\
161\end{array}$ & $\begin{array}{r}97,821 \\
11,370 \\
5,698 \\
76,276 \\
1,820 \\
2,657\end{array}$ & $\begin{array}{r}93,002 \\
10,527 \\
5,528 \\
72,577 \\
1,842 \\
2,528\end{array}$ & $\begin{array}{r}340 \\
\mathrm{~N} \\
93 \\
247 \\
- \\
-\end{array}$ & $\begin{array}{r}418 \\
\mathrm{~N} \\
68 \\
346 \\
1 \\
3\end{array}$ & $\begin{array}{r}424 \\
167 \\
74 \\
171 \\
1 \\
11\end{array}$ & $\begin{array}{r}474 \\
109 \\
107 \\
251 \\
7 \\
-\end{array}$ & $\begin{array}{r}375 \\
159 \\
68 \\
136 \\
1 \\
11\end{array}$ & $\begin{array}{r}412 \\
131 \\
101 \\
164 \\
- \\
16\end{array}$ \\
\hline $\begin{array}{l}\text { Guam } \\
\text { P.R. } \\
\text { V.I. } \\
\text { Amer. Samoa } \\
\text { C.N.M.I. }\end{array}$ & $\begin{array}{r}10 \\
1,180 \\
35 \\
- \\
-\end{array}$ & $\begin{array}{r}2 \\
1,601 \\
31 \\
- \\
-\end{array}$ & $\begin{array}{r}299 \\
U \\
U \\
U\end{array}$ & $\begin{array}{r}415 \\
U \\
U \\
U\end{array}$ & $\begin{array}{l}- \\
\\
U \\
U\end{array}$ & $\begin{array}{l}U_{U}^{N} \\
U\end{array}$ & $\begin{array}{l}\mathrm{N} \\
9 \\
U \\
U \\
U\end{array}$ & $\begin{array}{l}N \\
5 \\
U \\
U \\
U\end{array}$ & $\begin{array}{l}U \\
U \\
U \\
U\end{array}$ & $\begin{array}{l}U \\
U \\
U \\
U\end{array}$ \\
\hline
\end{tabular}

$\mathrm{N}$ : Not notifiable $\quad \mathrm{U}$ : Unavailable

-: no reported cases

C.N.M.I.: Commonwealth of Northern Mariana Islands

*Individual cases may be reported through both the National Electronic Telecommunications System for Surveillance (NETSS) and the Public Health Laboratory Information System (PHLIS).

tUpdated monthly from reports to the Division of HIV/AIDS Prevention-Surveillance and Epidemiology, National Center for HIV, STD, and TB Prevention, last update November 28, 1999. 
TABLE II. (Cont'd.) Provisional cases of selected notifiable diseases, United States, weeks ending December 18, 1999, and December 19, 1998 (50th Week)

\begin{tabular}{|c|c|c|c|c|c|c|c|c|}
\hline \multirow[b]{2}{*}{ Reporting Area } & \multicolumn{2}{|c|}{ Gonorrhea } & \multicolumn{2}{|c|}{$\begin{array}{l}\text { Hepatitis } \\
\text { C/NA,NB }\end{array}$} & \multicolumn{2}{|c|}{ Legionellosis } & \multicolumn{2}{|c|}{$\begin{array}{l}\text { Lyme } \\
\text { Disease }\end{array}$} \\
\hline & $\begin{array}{l}\text { Cum. } \\
1999\end{array}$ & $\begin{array}{l}\text { Cum. } \\
1998\end{array}$ & $\begin{array}{l}\text { Cum. } \\
1999\end{array}$ & $\begin{array}{l}\text { Cum. } \\
1998\end{array}$ & $\begin{array}{l}\text { Cum. } \\
1999\end{array}$ & $\begin{array}{l}\text { Cum. } \\
1998\end{array}$ & $\begin{array}{l}\text { Cum. } \\
1999\end{array}$ & $\begin{array}{l}\text { Cum. } \\
1998\end{array}$ \\
\hline UNITED STATES & 315,263 & 341,786 & 3,071 & 3,199 & 915 & 1,244 & 12,551 & 15,457 \\
\hline $\begin{array}{l}\text { NEW ENGLAND } \\
\text { Maine } \\
\text { N.H. } \\
\text { Vt. } \\
\text { Mass. } \\
\text { R.I. } \\
\text { Conn. }\end{array}$ & $\begin{array}{r}8,742 \\
71 \\
106 \\
47 \\
4,825 \\
572 \\
3,121\end{array}$ & $\begin{array}{r}5,845 \\
65 \\
89 \\
36 \\
2,197 \\
404 \\
3,054\end{array}$ & $\begin{array}{r}14 \\
2 \\
- \\
7 \\
2 \\
3 \\
-\end{array}$ & $\begin{array}{r}58 \\
- \\
- \\
6 \\
49 \\
3 \\
-\end{array}$ & $\begin{array}{r}82 \\
3 \\
8 \\
14 \\
31 \\
12 \\
14\end{array}$ & $\begin{array}{r}84 \\
1 \\
7 \\
7 \\
33 \\
21 \\
15\end{array}$ & $\begin{array}{r}3,549 \\
41 \\
23 \\
23 \\
967 \\
464 \\
2,031\end{array}$ & $\begin{array}{r}4,590 \\
78 \\
43 \\
11 \\
694 \\
650 \\
3,114\end{array}$ \\
\hline $\begin{array}{l}\text { MID. ATLANTIC } \\
\text { Upstate N.Y. } \\
\text { N.Y. City } \\
\text { N.J. } \\
\text { Pa. }\end{array}$ & $\begin{array}{r}36,151 \\
6,616 \\
11,762 \\
5,962 \\
11,811\end{array}$ & $\begin{array}{r}37,196 \\
7,047 \\
11,576 \\
7,653 \\
10,920\end{array}$ & $\begin{array}{r}95 \\
60 \\
- \\
- \\
35\end{array}$ & $\begin{array}{r}210 \\
105 \\
- \\
U \\
105\end{array}$ & $\begin{array}{r}186 \\
60 \\
9 \\
18 \\
99\end{array}$ & $\begin{array}{r}312 \\
107 \\
36 \\
18 \\
151\end{array}$ & $\begin{array}{r}7,078 \\
3,916 \\
41 \\
922 \\
2,199\end{array}$ & $\begin{array}{r}8,688 \\
4,041 \\
230 \\
1,859 \\
2,558\end{array}$ \\
\hline $\begin{array}{l}\text { E.N. CENTRAL } \\
\text { Ohio } \\
\text { Ind. } \\
\text { III. } \\
\text { Mich. } \\
\text { Wis. }\end{array}$ & $\begin{array}{r}55,121 \\
15,957 \\
5,972 \\
18,873 \\
14,319 \\
U\end{array}$ & $\begin{array}{r}66,962 \\
17,519 \\
6,376 \\
21,213 \\
15,674 \\
6,180\end{array}$ & $\begin{array}{r}1,435 \\
4 \\
1 \\
45 \\
794 \\
591\end{array}$ & $\begin{array}{r}658 \\
8 \\
5 \\
40 \\
464 \\
141\end{array}$ & $\begin{array}{r}248 \\
81 \\
46 \\
23 \\
60 \\
38\end{array}$ & $\begin{array}{r}408 \\
129 \\
77 \\
53 \\
82 \\
67\end{array}$ & $\begin{array}{r}177 \\
74 \\
21 \\
12 \\
1 \\
69\end{array}$ & $\begin{array}{r}756 \\
46 \\
37 \\
14 \\
12 \\
647\end{array}$ \\
\hline $\begin{array}{l}\text { W.N. CENTRAL } \\
\text { Minn. } \\
\text { lowa } \\
\text { Mo. } \\
\text { N. Dak. } \\
\text { S. Dak. } \\
\text { Nebr. } \\
\text { Kans. }\end{array}$ & $\begin{array}{r}14,357 \\
2,563 \\
1,155 \\
7,179 \\
71 \\
189 \\
1,374 \\
1,826\end{array}$ & $\begin{array}{r}16,994 \\
2,626 \\
1,468 \\
8,943 \\
78 \\
212 \\
1,134 \\
2,533\end{array}$ & $\begin{array}{r}299 \\
10 \\
- \\
277 \\
1 \\
- \\
5 \\
6\end{array}$ & $\begin{array}{r}44 \\
12 \\
8 \\
15 \\
- \\
- \\
5 \\
4\end{array}$ & $\begin{array}{r}53 \\
13 \\
14 \\
14 \\
2 \\
3 \\
3 \\
7 \\
-\end{array}$ & $\begin{array}{r}64 \\
7 \\
10 \\
16 \\
- \\
4 \\
19 \\
8\end{array}$ & $\begin{array}{r}290 \\
220 \\
20 \\
26 \\
1 \\
- \\
11 \\
12\end{array}$ & $\begin{array}{r}226 \\
173 \\
26 \\
12 \\
- \\
- \\
4 \\
11\end{array}$ \\
\hline $\begin{array}{l}\text { S. ATLANTIC } \\
\text { Del. } \\
\text { Md. } \\
\text { D.C. } \\
\text { Va. } \\
\text { W. Va. } \\
\text { N.C. } \\
\text { S.C. } \\
\text { Ga. } \\
\text { Fla. }\end{array}$ & $\begin{array}{r}92,066 \\
1,615 \\
9,151 \\
3,365 \\
9,151 \\
387 \\
18,440 \\
8,471 \\
21,117 \\
20,369\end{array}$ & $\begin{array}{r}91,941 \\
1,488 \\
9,463 \\
4,301 \\
9,244 \\
832 \\
18,410 \\
10,989 \\
18,840 \\
18,374\end{array}$ & $\begin{array}{r}190 \\
1 \\
41 \\
1 \\
11 \\
17 \\
34 \\
22 \\
1 \\
62\end{array}$ & $\begin{array}{r}118 \\
- \\
22 \\
- \\
12 \\
7 \\
25 \\
11 \\
9 \\
32\end{array}$ & $\begin{array}{r}148 \\
15 \\
32 \\
4 \\
39 \\
\mathrm{~N} \\
15 \\
11 \\
3 \\
29\end{array}$ & $\begin{array}{r}144 \\
13 \\
37 \\
8 \\
22 \\
\mathrm{~N} \\
14 \\
11 \\
8 \\
31\end{array}$ & $\begin{array}{r}1,146 \\
64 \\
806 \\
6 \\
118 \\
17 \\
73 \\
7 \\
- \\
55\end{array}$ & $\begin{array}{r}885 \\
66 \\
618 \\
4 \\
69 \\
13 \\
57 \\
7 \\
5 \\
46\end{array}$ \\
\hline $\begin{array}{l}\text { E.S. CENTRAL } \\
\text { Ky. } \\
\text { Tenn. } \\
\text { Ala. } \\
\text { Miss. }\end{array}$ & $\begin{array}{r}35,165 \\
3,192 \\
11,092 \\
10,938 \\
9,943\end{array}$ & $\begin{array}{r}38,376 \\
3,577 \\
11,753 \\
12,643 \\
10,403\end{array}$ & $\begin{array}{r}302 \\
24 \\
95 \\
1 \\
182\end{array}$ & $\begin{array}{r}273 \\
21 \\
164 \\
5 \\
83\end{array}$ & $\begin{array}{r}45 \\
20 \\
21 \\
4 \\
-\end{array}$ & $\begin{array}{r}65 \\
26 \\
23 \\
9 \\
7\end{array}$ & $\begin{array}{l}92 \\
10 \\
50 \\
19 \\
13\end{array}$ & $\begin{array}{r}111 \\
26 \\
44 \\
24 \\
17\end{array}$ \\
\hline $\begin{array}{l}\text { W.S. CENTRAL } \\
\text { Ark. } \\
\text { La. } \\
\text { Okla. } \\
\text { Tex. }\end{array}$ & $\begin{array}{r}44,770 \\
2,984 \\
8,880 \\
3,792 \\
29,114\end{array}$ & $\begin{array}{r}53,316 \\
3,852 \\
12,640 \\
5,054 \\
31,770\end{array}$ & $\begin{array}{r}314 \\
18 \\
102 \\
15 \\
179\end{array}$ & $\begin{array}{r}553 \\
22 \\
112 \\
20 \\
399\end{array}$ & $\begin{array}{r}23 \\
- \\
2 \\
3 \\
18\end{array}$ & $\begin{array}{r}34 \\
2 \\
4 \\
12 \\
16\end{array}$ & $\begin{array}{r}43 \\
4 \\
- \\
4 \\
35\end{array}$ & $\begin{array}{r}31 \\
7 \\
7 \\
2 \\
15\end{array}$ \\
\hline $\begin{array}{l}\text { MOUNTAIN } \\
\text { Mont. } \\
\text { Idaho } \\
\text { Wyo. } \\
\text { Colo. } \\
\text { N. Mex. } \\
\text { Ariz. } \\
\text { Utah } \\
\text { Nev. }\end{array}$ & $\begin{array}{r}8,939 \\
54 \\
82 \\
36 \\
2,316 \\
816 \\
4,211 \\
230 \\
1,194\end{array}$ & $\begin{array}{r}8,872 \\
48 \\
173 \\
34 \\
1,999 \\
928 \\
4,066 \\
217 \\
1,407\end{array}$ & $\begin{array}{r}154 \\
5 \\
8 \\
50 \\
23 \\
8 \\
46 \\
6 \\
8\end{array}$ & $\begin{array}{r}367 \\
7 \\
86 \\
93 \\
32 \\
97 \\
11 \\
21 \\
20\end{array}$ & $\begin{array}{r}49 \\
- \\
3 \\
- \\
13 \\
1 \\
7 \\
19 \\
6\end{array}$ & $\begin{array}{r}72 \\
2 \\
3 \\
1 \\
18 \\
2 \\
17 \\
21 \\
8\end{array}$ & $\begin{array}{r}18 \\
- \\
5 \\
3 \\
- \\
1 \\
2 \\
5 \\
2\end{array}$ & $\begin{array}{r}18 \\
- \\
6 \\
1 \\
- \\
4 \\
1 \\
- \\
6\end{array}$ \\
\hline $\begin{array}{l}\text { PACIFIC } \\
\text { Wash. } \\
\text { Oreg. } \\
\text { Calif. } \\
\text { Alaska } \\
\text { Hawaii }\end{array}$ & $\begin{array}{r}19,952 \\
2,013 \\
827 \\
16,436 \\
291 \\
385\end{array}$ & $\begin{array}{r}22,284 \\
1,887 \\
816 \\
18,776 \\
319 \\
486\end{array}$ & $\begin{array}{r}268 \\
20 \\
22 \\
226 \\
- \\
-\end{array}$ & $\begin{array}{r}918 \\
22 \\
19 \\
823 \\
- \\
54\end{array}$ & $\begin{array}{r}81 \\
17 \\
\mathrm{~N} \\
63 \\
1 \\
-\end{array}$ & $\begin{array}{r}61 \\
12 \\
\mathrm{~N} \\
47 \\
1 \\
1\end{array}$ & $\begin{array}{r}158 \\
10 \\
14 \\
134 \\
- \\
\mathrm{N}\end{array}$ & $\begin{array}{r}152 \\
7 \\
21 \\
123 \\
1 \\
\mathrm{~N}\end{array}$ \\
\hline $\begin{array}{l}\text { Guam } \\
\text { P.R. } \\
\text { V.I. } \\
\text { Amer. Samoa } \\
\text { C.N.M.I. }\end{array}$ & $\begin{array}{r}38 \\
332 \\
U \\
U\end{array}$ & $\begin{array}{r}71 \\
369 \\
\cup \\
U\end{array}$ & $\begin{array}{c}1 \\
- \\
\cup \\
\cup\end{array}$ & $\begin{array}{c}1 \\
- \\
\cup \\
\cup\end{array}$ & $\bigcup_{U}^{-}$ & $\begin{array}{c}2 \\
- \\
\cup \\
\cup\end{array}$ & $\begin{array}{l}\bar{N} \\
\cup \\
U\end{array}$ & $\begin{array}{l}1 \\
N \\
U \\
U\end{array}$ \\
\hline
\end{tabular}

$\mathrm{N}$ : Not notifiable

U: Unavailable

-: no reported cases 
TABLE II. (Cont'd.) Provisional cases of selected notifiable diseases, United States, weeks ending December 18, 1999, and December 19, 1998 (50th Week)

\begin{tabular}{|c|c|c|c|c|c|c|c|c|}
\hline \multirow[b]{3}{*}{ Reporting Area } & \multirow{2}{*}{\multicolumn{2}{|c|}{ Malaria }} & \multirow{2}{*}{\multicolumn{2}{|c|}{ Rabies, Animal }} & \multicolumn{4}{|c|}{ Salmonellosis* } \\
\hline & & & & & \multicolumn{2}{|c|}{ NETSS } & \multicolumn{2}{|c|}{ PHLIS } \\
\hline & $\begin{array}{l}\text { Cum. } \\
1999\end{array}$ & $\begin{array}{c}\text { Cum. } \\
1998\end{array}$ & $\begin{array}{l}\text { Cum. } \\
1999\end{array}$ & $\begin{array}{c}\text { Cum. } \\
1998\end{array}$ & $\begin{array}{l}\text { Cum. } \\
1999\end{array}$ & $\begin{array}{c}\text { Cum. } \\
1998\end{array}$ & $\begin{array}{l}\text { Cum. } \\
1999\end{array}$ & $\begin{array}{l}\text { Cum. } \\
1998\end{array}$ \\
\hline UNITED STATES & 1,290 & 1,438 & 5,713 & 7,021 & 36,829 & 41,026 & 29,407 & 32,856 \\
\hline $\begin{array}{l}\text { NEW ENGLAND } \\
\text { Maine } \\
\text { N.H. } \\
\text { Vt. } \\
\text { Mass. } \\
\text { R.I. } \\
\text { Conn. }\end{array}$ & $\begin{array}{r}66 \\
3 \\
2 \\
4 \\
24 \\
5 \\
28\end{array}$ & $\begin{array}{r}69 \\
5 \\
5 \\
1 \\
26 \\
14 \\
18\end{array}$ & $\begin{array}{r}869 \\
171 \\
50 \\
88 \\
218 \\
95 \\
247\end{array}$ & $\begin{array}{r}1,419 \\
234 \\
77 \\
68 \\
495 \\
99 \\
446\end{array}$ & $\begin{array}{r}2,126 \\
128 \\
136 \\
92 \\
1,135 \\
129 \\
506\end{array}$ & $\begin{array}{r}2,451 \\
163 \\
178 \\
141 \\
1,286 \\
142 \\
541\end{array}$ & $\begin{array}{r}2,050 \\
99 \\
140 \\
85 \\
1,137 \\
147 \\
442\end{array}$ & $\begin{array}{r}2,237 \\
66 \\
215 \\
113 \\
1,322 \\
34 \\
487\end{array}$ \\
\hline $\begin{array}{l}\text { MID. ATLANTIC } \\
\text { Upstate N.Y. } \\
\text { N.Y. City } \\
\text { N.J. } \\
\text { Pa. }\end{array}$ & $\begin{array}{r}326 \\
71 \\
169 \\
48 \\
38\end{array}$ & $\begin{array}{r}412 \\
88 \\
233 \\
57 \\
34\end{array}$ & $\begin{array}{r}1,105 \\
789 \\
U \\
166 \\
150\end{array}$ & $\begin{array}{r}1,561 \\
1,068 \\
U \\
218 \\
275\end{array}$ & $\begin{array}{r}4,708 \\
1,368 \\
1,333 \\
989 \\
1,018\end{array}$ & $\begin{array}{l}6,492 \\
1,559 \\
1,855 \\
1,459 \\
1,619\end{array}$ & $\begin{array}{r}4,082 \\
1,268 \\
1,173 \\
685 \\
956\end{array}$ & $\begin{array}{l}5,637 \\
1,333 \\
1,430 \\
1,358 \\
1,516\end{array}$ \\
\hline $\begin{array}{l}\text { E.N. CENTRAL } \\
\text { Ohio } \\
\text { Ind. } \\
\text { Ill. } \\
\text { Mich. } \\
\text { Wis. }\end{array}$ & $\begin{array}{r}143 \\
18 \\
21 \\
54 \\
40 \\
10\end{array}$ & $\begin{array}{r}141 \\
15 \\
10 \\
57 \\
47 \\
12\end{array}$ & $\begin{array}{r}146 \\
36 \\
13 \\
10 \\
87 \\
-\end{array}$ & $\begin{array}{r}123 \\
57 \\
12 \\
N \\
35 \\
19\end{array}$ & $\begin{array}{r}5,213 \\
1,279 \\
523 \\
1,515 \\
927 \\
969\end{array}$ & $\begin{array}{r}6,135 \\
1,465 \\
662 \\
1,886 \\
1,141 \\
981\end{array}$ & $\begin{array}{r}3,336 \\
1,046 \\
406 \\
399 \\
922 \\
563\end{array}$ & $\begin{array}{r}4,746 \\
1,118 \\
517 \\
1,549 \\
1,064 \\
498\end{array}$ \\
\hline $\begin{array}{l}\text { W.N. CENTRAL } \\
\text { Minn. } \\
\text { lowa } \\
\text { Mo. } \\
\text { N. Dak. } \\
\text { S. Dak. } \\
\text { Nebr. } \\
\text { Kans. }\end{array}$ & $\begin{array}{r}73 \\
41 \\
13 \\
14 \\
- \\
- \\
1 \\
4\end{array}$ & $\begin{array}{r}99 \\
63 \\
7 \\
14 \\
3 \\
1 \\
1 \\
10\end{array}$ & $\begin{array}{r}671 \\
112 \\
155 \\
14 \\
137 \\
163 \\
3 \\
87\end{array}$ & $\begin{array}{r}694 \\
116 \\
147 \\
42 \\
143 \\
151 \\
7 \\
88\end{array}$ & $\begin{array}{r}2,144 \\
629 \\
258 \\
689 \\
51 \\
96 \\
202 \\
219\end{array}$ & $\begin{array}{r}2,239 \\
564 \\
353 \\
605 \\
60 \\
124 \\
187 \\
346\end{array}$ & $\begin{array}{r}2,206 \\
662 \\
197 \\
888 \\
49 \\
116 \\
78 \\
216\end{array}$ & $\begin{array}{r}2,276 \\
642 \\
286 \\
833 \\
67 \\
129 \\
46 \\
273\end{array}$ \\
\hline $\begin{array}{l}\text { S. ATLANTIC } \\
\text { Del. } \\
\text { Md. } \\
\text { D.C. } \\
\text { Va. } \\
\text { W. Va. } \\
\text { N.C. } \\
\text { S.C. } \\
\text { Ga. } \\
\text { Fla. }\end{array}$ & $\begin{array}{r}344 \\
1 \\
94 \\
18 \\
71 \\
3 \\
31 \\
17 \\
29 \\
80\end{array}$ & $\begin{array}{r}308 \\
3 \\
88 \\
19 \\
59 \\
2 \\
29 \\
6 \\
37 \\
65\end{array}$ & $\begin{array}{r}2,049 \\
43 \\
389 \\
- \\
561 \\
106 \\
404 \\
133 \\
231 \\
182\end{array}$ & $\begin{array}{r}2,274 \\
49 \\
434 \\
- \\
538 \\
76 \\
548 \\
144 \\
290 \\
195\end{array}$ & $\begin{array}{r}8,698 \\
139 \\
860 \\
69 \\
1,225 \\
163 \\
1,269 \\
682 \\
1,509 \\
2,782\end{array}$ & $\begin{array}{r}8,439 \\
77 \\
898 \\
83 \\
1,074 \\
150 \\
1,255 \\
613 \\
1,692 \\
2,597\end{array}$ & $\begin{array}{r}6,100 \\
153 \\
983 \\
U \\
980 \\
150 \\
1,243 \\
492 \\
1,644 \\
455\end{array}$ & $\begin{array}{r}6,018 \\
118 \\
878 \\
U \\
844 \\
161 \\
1,400 \\
534 \\
1,520 \\
563\end{array}$ \\
\hline $\begin{array}{l}\text { E.S. CENTRAL } \\
\text { Ky. } \\
\text { Tenn. } \\
\text { Ala. } \\
\text { Miss. }\end{array}$ & $\begin{array}{r}24 \\
7 \\
8 \\
7 \\
2\end{array}$ & $\begin{array}{r}34 \\
7 \\
16 \\
6 \\
5\end{array}$ & $\begin{array}{r}252 \\
35 \\
93 \\
123 \\
1\end{array}$ & $\begin{array}{r}269 \\
31 \\
139 \\
97 \\
2\end{array}$ & $\begin{array}{r}2,081 \\
400 \\
513 \\
588 \\
580\end{array}$ & $\begin{array}{r}2,303 \\
355 \\
587 \\
684 \\
677\end{array}$ & $\begin{array}{r}1,066 \\
- \\
513 \\
476 \\
77\end{array}$ & $\begin{array}{r}1,550 \\
124 \\
702 \\
566 \\
158\end{array}$ \\
\hline $\begin{array}{l}\text { W.S. CENTRAL } \\
\text { Ark. } \\
\text { La. } \\
\text { Okla. } \\
\text { Tex. }\end{array}$ & $\begin{array}{r}16 \\
3 \\
10 \\
2 \\
1\end{array}$ & $\begin{array}{r}54 \\
1 \\
14 \\
3 \\
36\end{array}$ & $\begin{array}{r}94 \\
14 \\
- \\
80 \\
-\end{array}$ & $\begin{array}{r}28 \\
28 \\
- \\
\mathrm{N} \\
-\end{array}$ & $\begin{array}{r}3,598 \\
626 \\
334 \\
406 \\
2,232\end{array}$ & $\begin{array}{r}4,777 \\
594 \\
749 \\
473 \\
2,961\end{array}$ & $\begin{array}{r}3,546 \\
120 \\
568 \\
320 \\
2,538\end{array}$ & $\begin{array}{r}3,139 \\
372 \\
795 \\
228 \\
1,744\end{array}$ \\
\hline $\begin{array}{l}\text { MOUNTAIN } \\
\text { Mont. } \\
\text { Idaho } \\
\text { Wyo. } \\
\text { Colo. } \\
\text { N. Mex. } \\
\text { Ariz. } \\
\text { Utah } \\
\text { Nev. }\end{array}$ & $\begin{array}{r}44 \\
4 \\
3 \\
1 \\
17 \\
2 \\
2 \\
9 \\
4 \\
4\end{array}$ & $\begin{array}{r}62 \\
1 \\
8 \\
- \\
18 \\
12 \\
9 \\
2 \\
12\end{array}$ & $\begin{array}{r}197 \\
59 \\
5 \\
44 \\
1 \\
9 \\
66 \\
8 \\
5\end{array}$ & $\begin{array}{r}249 \\
54 \\
\mathrm{~N} \\
66 \\
42 \\
6 \\
48 \\
27 \\
6\end{array}$ & $\begin{array}{r}2,997 \\
81 \\
127 \\
67 \\
690 \\
368 \\
932 \\
547 \\
185\end{array}$ & $\begin{array}{r}2,469 \\
76 \\
120 \\
64 \\
526 \\
293 \\
802 \\
347 \\
241\end{array}$ & $\begin{array}{r}2,437 \\
1 \\
98 \\
49 \\
689 \\
245 \\
783 \\
519 \\
53\end{array}$ & $\begin{array}{r}1,974 \\
43 \\
95 \\
59 \\
493 \\
260 \\
680 \\
122 \\
222\end{array}$ \\
\hline $\begin{array}{l}\text { PACIFIC } \\
\text { Wash. } \\
\text { Oreg. } \\
\text { Calif. } \\
\text { Alaska } \\
\text { Hawaii }\end{array}$ & $\begin{array}{r}254 \\
28 \\
21 \\
192 \\
1 \\
12\end{array}$ & $\begin{array}{r}259 \\
20 \\
16 \\
210 \\
4 \\
9\end{array}$ & $\begin{array}{r}330 \\
- \\
2 \\
321 \\
7 \\
-\end{array}$ & $\begin{array}{r}404 \\
- \\
7 \\
374 \\
23 \\
-\end{array}$ & $\begin{array}{r}5,264 \\
643 \\
409 \\
3,833 \\
53 \\
326\end{array}$ & $\begin{array}{r}5,721 \\
501 \\
318 \\
4,553 \\
56 \\
293\end{array}$ & $\begin{array}{r}4,584 \\
795 \\
497 \\
2,996 \\
30 \\
266\end{array}$ & $\begin{array}{r}5,279 \\
677 \\
327 \\
3,938 \\
37 \\
300\end{array}$ \\
\hline $\begin{array}{l}\text { Guam } \\
\text { P.R. } \\
\text { V.I. } \\
\text { Amer. Samoa } \\
\text { C.N.M.I. }\end{array}$ & $\begin{array}{l}- \\
\text { U } \\
\text { U }\end{array}$ & $\begin{array}{l}2 \\
- \\
\cup \\
U\end{array}$ & $\begin{array}{r}- \\
\cup \\
\cup\end{array}$ & $\begin{array}{r}50 \\
\cup \\
\cup\end{array}$ & $\begin{array}{r}24 \\
460 \\
U \\
\cup \\
U\end{array}$ & $\begin{array}{r}44 \\
795 \\
\cup \\
\cup \\
U\end{array}$ & $\begin{array}{l}U \\
\cup \\
\cup\end{array}$ & $\begin{array}{l}U \\
U \\
U\end{array}$ \\
\hline
\end{tabular}

$\mathrm{N}$ : Not notifiable $\quad \mathrm{U}$ : Unavailable $\quad$-: no reported cases

*Individual cases may be reported through both the National Electronic Telecommunications System for Surveillance (NETSS) and the Public Health Laboratory Information System (PHLIS). 
TABLE II. (Cont'd.) Provisional cases of selected notifiable diseases, United States, weeks ending December 18, 1999, and December 19, 1998 (50th Week)

\begin{tabular}{|c|c|c|c|c|c|c|c|c|}
\hline \multirow[b]{3}{*}{ Reporting Area } & \multicolumn{4}{|c|}{ Shigellosis* } & \multirow{2}{*}{\multicolumn{2}{|c|}{$\begin{array}{c}\text { Syphilis } \\
\text { (Primary \& Secondary) }\end{array}$}} & \multirow{2}{*}{\multicolumn{2}{|c|}{ Tuberculosis }} \\
\hline & \multicolumn{2}{|c|}{ NETSS } & \multicolumn{2}{|c|}{ PHLIS } & & & & \\
\hline & $\begin{array}{c}\text { Cum. } \\
1999\end{array}$ & $\begin{array}{c}\text { Cum. } \\
1998\end{array}$ & $\begin{array}{l}\text { Cum. } \\
1999\end{array}$ & $\begin{array}{l}\text { Cum. } \\
1998\end{array}$ & $\begin{array}{l}\text { Cum. } \\
1999\end{array}$ & $\begin{array}{l}\text { Cum. } \\
1998\end{array}$ & $\begin{array}{l}\text { Cum. } \\
1^{1999^{\dagger}}\end{array}$ & $\begin{array}{l}\text { Cum. } \\
1998^{\dagger}\end{array}$ \\
\hline UNITED STATES & 15,351 & 21,622 & 7,515 & 12,056 & 6,036 & 6,827 & 13,398 & 16,565 \\
\hline $\begin{array}{l}\text { NEW ENGLAND } \\
\text { Maine } \\
\text { N.H. } \\
\text { Vt. } \\
\text { Mass. } \\
\text { R.I. } \\
\text { Conn. }\end{array}$ & $\begin{array}{r}839 \\
5 \\
17 \\
6 \\
713 \\
31 \\
67\end{array}$ & $\begin{array}{r}405 \\
14 \\
16 \\
7 \\
261 \\
36 \\
71\end{array}$ & $\begin{array}{r}786 \\
- \\
17 \\
4 \\
687 \\
18 \\
60\end{array}$ & $\begin{array}{r}358 \\
- \\
22 \\
4 \\
254 \\
13 \\
65\end{array}$ & $\begin{array}{r}93 \\
- \\
1 \\
3 \\
70 \\
3 \\
16\end{array}$ & $\begin{array}{r}77 \\
1 \\
2 \\
4 \\
43 \\
1 \\
26\end{array}$ & $\begin{array}{r}413 \\
18 \\
10 \\
2 \\
234 \\
39 \\
110\end{array}$ & $\begin{array}{r}438 \\
12 \\
- \\
5 \\
262 \\
52 \\
107\end{array}$ \\
\hline $\begin{array}{l}\text { MID. ATLANTIC } \\
\text { Upstate N.Y. } \\
\text { N.Y. City } \\
\text { N.J. } \\
\text { Pa. }\end{array}$ & $\begin{array}{l}923 \\
284 \\
289 \\
194 \\
156\end{array}$ & $\begin{array}{r}2,328 \\
624 \\
698 \\
657 \\
349\end{array}$ & $\begin{array}{r}454 \\
67 \\
82 \\
155 \\
150\end{array}$ & $\begin{array}{r}1,662 \\
223 \\
577 \\
608 \\
254\end{array}$ & $\begin{array}{r}186 \\
23 \\
79 \\
51 \\
33\end{array}$ & $\begin{array}{r}321 \\
37 \\
83 \\
105 \\
96\end{array}$ & $\begin{array}{r}2,409 \\
308 \\
1,286 \\
479 \\
336\end{array}$ & $\begin{array}{r}2,989 \\
367 \\
1,399 \\
606 \\
617\end{array}$ \\
\hline $\begin{array}{l}\text { E.N. CENTRAL } \\
\text { Ohio } \\
\text { Ind. } \\
\text { III. } \\
\text { Mich. } \\
\text { Wis. }\end{array}$ & $\begin{array}{r}2,912 \\
416 \\
332 \\
1,089 \\
489 \\
586\end{array}$ & $\begin{array}{r}2,931 \\
537 \\
175 \\
1,538 \\
270 \\
411\end{array}$ & $\begin{array}{r}1,293 \\
141 \\
101 \\
592 \\
382 \\
77\end{array}$ & $\begin{array}{r}1,540 \\
145 \\
43 \\
1,279 \\
4 \\
69\end{array}$ & $\begin{array}{r}1,126 \\
87 \\
424 \\
385 \\
230 \\
U\end{array}$ & $\begin{array}{r}996 \\
130 \\
208 \\
405 \\
194 \\
59\end{array}$ & $\begin{array}{r}1,273 \\
248 \\
137 \\
531 \\
272 \\
85\end{array}$ & $\begin{array}{r}1,635 \\
224 \\
158 \\
791 \\
355 \\
107\end{array}$ \\
\hline $\begin{array}{l}\text { W.N. CENTRAL } \\
\text { Minn. } \\
\text { lowa } \\
\text { Mo. } \\
\text { N. Dak. } \\
\text { S. Dak. } \\
\text { Nebr. } \\
\text { Kans. }\end{array}$ & $\begin{array}{r}1,096 \\
249 \\
67 \\
638 \\
3 \\
18 \\
84 \\
37\end{array}$ & $\begin{array}{r}1,051 \\
298 \\
67 \\
200 \\
10 \\
32 \\
369 \\
75\end{array}$ & $\begin{array}{r}723 \\
229 \\
48 \\
352 \\
2 \\
10 \\
35 \\
47\end{array}$ & $\begin{array}{r}612 \\
327 \\
45 \\
134 \\
3 \\
23 \\
19 \\
61\end{array}$ & $\begin{array}{r}108 \\
9 \\
9 \\
72 \\
- \\
- \\
8 \\
10\end{array}$ & $\begin{array}{r}133 \\
9 \\
3 \\
100 \\
- \\
1 \\
7 \\
13\end{array}$ & $\begin{array}{r}453 \\
189 \\
54 \\
152 \\
6 \\
17 \\
16 \\
19\end{array}$ & $\begin{array}{r}475 \\
148 \\
51 \\
166 \\
10 \\
17 \\
30 \\
53\end{array}$ \\
\hline $\begin{array}{l}\text { S. ATLANTIC } \\
\text { Del. } \\
\text { Md. } \\
\text { D.C. } \\
\text { Va. } \\
\text { W. Va. } \\
\text { N.C. } \\
\text { S.C. } \\
\text { Ga. } \\
\text { Fla. }\end{array}$ & $\begin{array}{r}2,428 \\
13 \\
159 \\
51 \\
130 \\
8 \\
200 \\
124 \\
231 \\
1,512\end{array}$ & $\begin{array}{r}4,220 \\
46 \\
200 \\
37 \\
195 \\
11 \\
346 \\
183 \\
1,060 \\
2,142\end{array}$ & $\begin{array}{r}492 \\
9 \\
58 \\
\cup \\
61 \\
5 \\
86 \\
62 \\
85 \\
126\end{array}$ & $\begin{array}{r}1,251 \\
37 \\
67 \\
\cup \\
87 \\
8 \\
180 \\
97 \\
246 \\
529\end{array}$ & $\begin{array}{r}1,941 \\
8 \\
311 \\
60 \\
150 \\
2 \\
421 \\
246 \\
407 \\
336\end{array}$ & $\begin{array}{r}2,490 \\
21 \\
656 \\
85 \\
144 \\
3 \\
706 \\
313 \\
287 \\
275\end{array}$ & $\begin{array}{r}2,813 \\
12 \\
259 \\
49 \\
268 \\
37 \\
394 \\
222 \\
565 \\
1,007\end{array}$ & $\begin{array}{r}3,084 \\
34 \\
286 \\
103 \\
280 \\
41 \\
491 \\
270 \\
515 \\
1,064\end{array}$ \\
\hline $\begin{array}{l}\text { E.S. CENTRAL } \\
\text { Ky. } \\
\text { Tenn. } \\
\text { Ala. } \\
\text { Miss. }\end{array}$ & $\begin{array}{r}1,102 \\
231 \\
600 \\
117 \\
154\end{array}$ & $\begin{array}{r}1,512 \\
151 \\
855 \\
451 \\
55\end{array}$ & $\begin{array}{r}485 \\
- \\
428 \\
47 \\
10\end{array}$ & $\begin{array}{r}1,173 \\
45 \\
901 \\
220 \\
7\end{array}$ & $\begin{array}{r}1,119 \\
99 \\
630 \\
205 \\
185\end{array}$ & $\begin{array}{r}1,185 \\
103 \\
561 \\
271 \\
250\end{array}$ & $\begin{array}{r}846 \\
166 \\
333 \\
291 \\
56\end{array}$ & $\begin{array}{r}1,190 \\
157 \\
458 \\
369 \\
206\end{array}$ \\
\hline $\begin{array}{l}\text { W.S. CENTRAL } \\
\text { Ark. } \\
\text { La. } \\
\text { Okla. } \\
\text { Tex. }\end{array}$ & $\begin{array}{r}2,438 \\
74 \\
118 \\
456 \\
1,790\end{array}$ & $\begin{array}{r}4,545 \\
202 \\
333 \\
636 \\
3,374\end{array}$ & $\begin{array}{r}2,337 \\
23 \\
128 \\
153 \\
2,033\end{array}$ & $\begin{array}{r}1,420 \\
64 \\
285 \\
198 \\
873\end{array}$ & $\begin{array}{r}896 \\
79 \\
208 \\
175 \\
434\end{array}$ & $\begin{array}{r}1,044 \\
108 \\
419 \\
96 \\
421\end{array}$ & $\begin{array}{r}1,469 \\
161 \\
U \\
129 \\
1,179\end{array}$ & $\begin{array}{r}2,373 \\
144 \\
278 \\
161 \\
1,790\end{array}$ \\
\hline $\begin{array}{l}\text { MOUNTAIN } \\
\text { Mont. } \\
\text { Idaho } \\
\text { Wyo. } \\
\text { Colo. } \\
\text { N. Mex. } \\
\text { Ariz. } \\
\text { Utah } \\
\text { Nev. }\end{array}$ & $\begin{array}{r}1,158 \\
9 \\
28 \\
3 \\
194 \\
150 \\
614 \\
70 \\
90\end{array}$ & $\begin{array}{r}1,262 \\
8 \\
20 \\
3 \\
225 \\
296 \\
598 \\
47 \\
65\end{array}$ & $\begin{array}{r}731 \\
- \\
12 \\
1 \\
155 \\
94 \\
399 \\
64 \\
6\end{array}$ & $\begin{array}{r}746 \\
3 \\
14 \\
1 \\
164 \\
176 \\
333 \\
35 \\
20\end{array}$ & $\begin{array}{r}230 \\
1 \\
1 \\
- \\
2 \\
11 \\
207 \\
2 \\
6\end{array}$ & $\begin{array}{r}229 \\
- \\
2 \\
1 \\
10 \\
22 \\
175 \\
4 \\
15\end{array}$ & $\begin{array}{r}429 \\
13 \\
15 \\
3 \\
U \\
62 \\
215 \\
39 \\
82\end{array}$ & $\begin{array}{r}548 \\
19 \\
11 \\
4 \\
72 \\
67 \\
211 \\
49 \\
115\end{array}$ \\
\hline $\begin{array}{l}\text { PACIFIC } \\
\text { Wash. } \\
\text { Oreg. } \\
\text { Calif. } \\
\text { Alaska } \\
\text { Hawaii }\end{array}$ & $\begin{array}{r}2,455 \\
118 \\
95 \\
2,205 \\
4 \\
33\end{array}$ & $\begin{array}{r}3,368 \\
224 \\
190 \\
2,893 \\
11 \\
50\end{array}$ & $\begin{array}{r}214 \\
99 \\
85 \\
- \\
3 \\
27\end{array}$ & $\begin{array}{r}3,294 \\
190 \\
154 \\
2,893 \\
7 \\
50\end{array}$ & $\begin{array}{r}337 \\
64 \\
10 \\
259 \\
1 \\
3\end{array}$ & $\begin{array}{r}352 \\
27 \\
5 \\
316 \\
1 \\
3\end{array}$ & $\begin{array}{r}3,293 \\
168 \\
99 \\
2,793 \\
59 \\
174\end{array}$ & $\begin{array}{r}3,833 \\
255 \\
130 \\
3,222 \\
54 \\
172\end{array}$ \\
\hline $\begin{array}{l}\text { Guam } \\
\text { P.R. } \\
\text { V.I. } \\
\text { Amer. Samoa } \\
\text { C.N.M.I. }\end{array}$ & $\begin{array}{r}8 \\
111 \\
U \\
U \\
U\end{array}$ & $\begin{array}{l}39 \\
63 \\
\cup \\
\cup \\
U\end{array}$ & $\begin{array}{l}U \\
U \\
U \\
U\end{array}$ & $\begin{array}{l}U \\
U \\
U \\
U \\
U\end{array}$ & $\begin{array}{r}1 \\
155 \\
\cup \\
\cup \\
\cup\end{array}$ & $\begin{array}{r}1 \\
170 \\
U \\
\cup\end{array}$ & $\begin{array}{r}11 \\
41 \\
\cup \\
\cup\end{array}$ & $\begin{array}{r}84 \\
140 \\
U \\
U \\
U\end{array}$ \\
\hline
\end{tabular}

$\mathrm{N}$ : Not notifiable U: Unavailable

$\therefore$ no reported cases

*Individual cases may be reported through both the National Electronic Telecommunications System for Surveillance (NETSS) and the Public Health Laboratory Information System (PHLIS).

†Cumulative reports of provisional tuberculosis cases for 1999 are unavailable ("U") for some areas using the Tuberculosis Information System (TIMS). 
TABLE III. Provisional cases of selected notifiable diseases preventable by vaccination, United States, weeks ending December 18, 1999, and December 19, 1998 (50th Week)

\begin{tabular}{|c|c|c|c|c|c|c|c|c|c|c|c|c|}
\hline \multirow[b]{3}{*}{ Reporting Area } & \multirow{2}{*}{\multicolumn{2}{|c|}{$\begin{array}{l}\text { H. influenzae, } \\
\text { invasive }\end{array}$}} & \multicolumn{4}{|c|}{ Hepatitis (Viral), by type } & \multicolumn{6}{|c|}{ Measles (Rubeola) } \\
\hline & & & \multicolumn{2}{|c|}{ A } & \multicolumn{2}{|c|}{ B } & \multicolumn{2}{|c|}{ Indigenous } & \multicolumn{2}{|c|}{ Imported* } & \multicolumn{2}{|c|}{ Total } \\
\hline & $\begin{array}{l}\text { Cum. } \\
\text { 1999 }^{\dagger}\end{array}$ & $\begin{array}{l}\text { Cum. } \\
1998\end{array}$ & $\begin{array}{l}\text { Cum. } \\
1999\end{array}$ & $\begin{array}{l}\text { Cum. } \\
1998 \\
\end{array}$ & $\begin{array}{l}\text { Cum. } \\
1999\end{array}$ & $\begin{array}{l}\text { Cum. } \\
1998\end{array}$ & 1999 & $\begin{array}{l}\text { Cum. } \\
1999\end{array}$ & 1999 & $\begin{array}{l}\text { Cum. } \\
1999\end{array}$ & $\begin{array}{l}\text { Cum. } \\
1999 \\
\end{array}$ & $\begin{array}{l}\text { Cum. } \\
1998\end{array}$ \\
\hline UNITED STATES & 1,105 & 1,029 & 16,017 & 21,471 & 6,130 & 9,235 & - & 60 & - & 25 & 85 & 90 \\
\hline $\begin{array}{l}\text { NEW ENGLAND } \\
\text { Maine } \\
\text { N.H. } \\
\text { Vt. } \\
\text { Mass. } \\
\text { R.I. } \\
\text { Conn. }\end{array}$ & $\begin{array}{r}98 \\
8 \\
21 \\
5 \\
37 \\
6 \\
21\end{array}$ & $\begin{array}{r}69 \\
4 \\
10 \\
9 \\
39 \\
6 \\
1\end{array}$ & $\begin{array}{r}293 \\
14 \\
18 \\
19 \\
113 \\
26 \\
103\end{array}$ & $\begin{array}{r}287 \\
20 \\
15 \\
17 \\
122 \\
17 \\
96\end{array}$ & $\begin{array}{r}134 \\
1 \\
16 \\
3 \\
41 \\
34 \\
39\end{array}$ & $\begin{array}{r}214 \\
5 \\
19 \\
10 \\
78 \\
68 \\
34\end{array}$ & $\begin{array}{l}- \\
\\
- \\
- \\
- \\
-\end{array}$ & $\begin{array}{l}6 \\
- \\
- \\
- \\
5 \\
- \\
1\end{array}$ & $\begin{array}{l}- \\
\\
- \\
- \\
- \\
-\end{array}$ & $\begin{array}{l}5 \\
- \\
1 \\
- \\
3 \\
- \\
1\end{array}$ & $\begin{array}{r}11 \\
- \\
1 \\
- \\
8 \\
- \\
2\end{array}$ & $\begin{array}{l}3 \\
- \\
- \\
1 \\
2 \\
- \\
-\end{array}$ \\
\hline $\begin{array}{l}\text { MID. ATLANTIC } \\
\text { Upstate N.Y. } \\
\text { N.Y. City } \\
\text { N.J. } \\
\text { Pa. }\end{array}$ & $\begin{array}{r}173 \\
80 \\
41 \\
49 \\
3\end{array}$ & $\begin{array}{r}168 \\
63 \\
43 \\
51 \\
11\end{array}$ & $\begin{array}{l}932 \\
265 \\
310 \\
112 \\
245\end{array}$ & $\begin{array}{r}1,656 \\
350 \\
584 \\
334 \\
388\end{array}$ & $\begin{array}{r}575 \\
176 \\
202 \\
41 \\
156\end{array}$ & $\begin{array}{r}1,188 \\
234 \\
412 \\
201 \\
341\end{array}$ & $\begin{array}{l}- \\
- \\
\\
-\end{array}$ & $\begin{array}{l}- \\
- \\
- \\
-\end{array}$ & $\begin{array}{l}- \\
- \\
\\
-\end{array}$ & $\begin{array}{l}2 \\
2 \\
- \\
- \\
-\end{array}$ & $\begin{array}{l}2 \\
2 \\
- \\
- \\
-\end{array}$ & $\begin{array}{r}14 \\
2 \\
- \\
8 \\
4\end{array}$ \\
\hline $\begin{array}{l}\text { E.N. CENTRAL } \\
\text { Ohio } \\
\text { Ind. } \\
\text { III. } \\
\text { Mich. } \\
\text { Wis. }\end{array}$ & $\begin{array}{r}163 \\
58 \\
24 \\
66 \\
14 \\
1\end{array}$ & $\begin{array}{r}174 \\
47 \\
43 \\
64 \\
13 \\
7\end{array}$ & $\begin{array}{r}2,727 \\
644 \\
109 \\
707 \\
1,200 \\
67\end{array}$ & $\begin{array}{r}3,557 \\
359 \\
163 \\
779 \\
2,073 \\
183\end{array}$ & $\begin{array}{r}638 \\
90 \\
43 \\
1 \\
480 \\
24\end{array}$ & $\begin{array}{r}1,379 \\
75 \\
109 \\
226 \\
472 \\
497\end{array}$ & $\begin{array}{l}- \\
- \\
- \\
- \\
\end{array}$ & $\begin{array}{l}1 \\
- \\
1 \\
- \\
- \\
-\end{array}$ & $\begin{array}{l}- \\
- \\
- \\
- \\
-\end{array}$ & $\begin{array}{l}2 \\
- \\
1 \\
- \\
1 \\
-\end{array}$ & $\begin{array}{l}3 \\
- \\
2 \\
- \\
1 \\
-\end{array}$ & $\begin{array}{r}16 \\
1 \\
3 \\
1 \\
10 \\
1\end{array}$ \\
\hline $\begin{array}{l}\text { W.N. CENTRAL } \\
\text { Minn. } \\
\text { lowa } \\
\text { Mo. } \\
\text { N. Dak. } \\
\text { S. Dak. } \\
\text { Nebr. } \\
\text { Kans. }\end{array}$ & $\begin{array}{r}86 \\
47 \\
8 \\
22 \\
1 \\
1 \\
3 \\
4\end{array}$ & $\begin{array}{r}88 \\
66 \\
3 \\
11 \\
- \\
1 \\
1 \\
6\end{array}$ & $\begin{array}{r}884 \\
95 \\
144 \\
534 \\
3 \\
9 \\
99 \\
59 \\
40\end{array}$ & $\begin{array}{r}1,295 \\
130 \\
399 \\
593 \\
3 \\
39 \\
26 \\
105\end{array}$ & $\begin{array}{r}348 \\
54 \\
39 \\
207 \\
2 \\
1 \\
18 \\
27\end{array}$ & $\begin{array}{r}399 \\
49 \\
54 \\
241 \\
4 \\
2 \\
22 \\
27\end{array}$ & $\begin{array}{l}- \\
- \\
- \\
- \\
\\
- \\
\end{array}$ & $\begin{array}{l}1 \\
1 \\
- \\
- \\
- \\
- \\
- \\
-\end{array}$ & $\begin{array}{l}- \\
- \\
- \\
- \\
\\
- \\
\end{array}$ & $\begin{array}{l}- \\
- \\
- \\
- \\
- \\
- \\
-\end{array}$ & $\begin{array}{l}1 \\
1 \\
- \\
- \\
- \\
- \\
- \\
-\end{array}$ & $\begin{array}{l}- \\
- \\
- \\
- \\
- \\
- \\
- \\
-\end{array}$ \\
\hline $\begin{array}{l}\text { S. ATLANTIC } \\
\text { Del. } \\
\text { Md. } \\
\text { D.C. } \\
\text { Va. } \\
\text { W. Va. } \\
\text { N.C. } \\
\text { S.C. } \\
\text { Ga. } \\
\text { Fla. }\end{array}$ & $\begin{array}{r}258 \\
- \\
68 \\
5 \\
22 \\
7 \\
35 \\
6 \\
68 \\
47\end{array}$ & $\begin{array}{r}184 \\
1 \\
53 \\
- \\
19 \\
6 \\
24 \\
3 \\
50 \\
28\end{array}$ & $\begin{array}{r}1,996 \\
2 \\
350 \\
59 \\
175 \\
39 \\
156 \\
47 \\
449 \\
719\end{array}$ & $\begin{array}{r}1,980 \\
6 \\
399 \\
64 \\
213 \\
7 \\
123 \\
46 \\
650 \\
472\end{array}$ & $\begin{array}{r}1,207 \\
1 \\
166 \\
24 \\
96 \\
23 \\
212 \\
65 \\
177 \\
443\end{array}$ & $\begin{array}{r}1,042 \\
4 \\
135 \\
18 \\
99 \\
10 \\
243 \\
52 \\
145 \\
336\end{array}$ & $\begin{array}{l}- \\
- \\
- \\
- \\
- \\
- \\
\\
- \\
- \\
-\end{array}$ & $\begin{array}{r}14 \\
- \\
- \\
- \\
14 \\
- \\
- \\
- \\
- \\
-\end{array}$ & $\begin{array}{l}- \\
- \\
- \\
- \\
- \\
- \\
U \\
- \\
- \\
-\end{array}$ & $\begin{array}{l}6 \\
- \\
- \\
- \\
4 \\
- \\
- \\
- \\
- \\
2\end{array}$ & $\begin{array}{r}20 \\
- \\
- \\
- \\
18 \\
- \\
- \\
- \\
- \\
2\end{array}$ & $\begin{array}{l}8 \\
1 \\
1 \\
- \\
2 \\
- \\
- \\
- \\
2 \\
2\end{array}$ \\
\hline $\begin{array}{l}\text { E.S. CENTRAL } \\
\text { Ky. } \\
\text { Tenn. } \\
\text { Ala. } \\
\text { Miss. }\end{array}$ & $\begin{array}{r}62 \\
7 \\
35 \\
17 \\
3\end{array}$ & $\begin{array}{r}61 \\
7 \\
36 \\
15 \\
3\end{array}$ & $\begin{array}{r}403 \\
63 \\
174 \\
55 \\
111\end{array}$ & $\begin{array}{r}401 \\
32 \\
221 \\
79 \\
69\end{array}$ & $\begin{array}{r}462 \\
43 \\
211 \\
78 \\
130\end{array}$ & $\begin{array}{r}483 \\
48 \\
268 \\
73 \\
94\end{array}$ & $\begin{array}{l}\bar{U} \\
- \\
- \\
-\end{array}$ & $\begin{array}{l}2 \\
2 \\
- \\
- \\
-\end{array}$ & $\begin{array}{c}- \\
\\
- \\
-\end{array}$ & $\begin{array}{l}- \\
- \\
- \\
- \\
-\end{array}$ & $\begin{array}{l}2 \\
2 \\
- \\
- \\
-\end{array}$ & $\begin{array}{l}2 \\
- \\
1 \\
1 \\
-\end{array}$ \\
\hline $\begin{array}{l}\text { W.S. CENTRAL } \\
\text { Ark. } \\
\text { La. } \\
\text { Okla. } \\
\text { Tex. }\end{array}$ & $\begin{array}{r}46 \\
2 \\
7 \\
33 \\
4\end{array}$ & $\begin{array}{r}54 \\
- \\
21 \\
30 \\
3\end{array}$ & $\begin{array}{r}3,612 \\
68 \\
73 \\
435 \\
3,036\end{array}$ & $\begin{array}{r}3,908 \\
79 \\
114 \\
605 \\
3,110\end{array}$ & $\begin{array}{r}803 \\
69 \\
77 \\
129 \\
528\end{array}$ & $\begin{array}{r}2,027 \\
104 \\
163 \\
121 \\
1,639\end{array}$ & $\begin{array}{c}\bar{U} \\
\bar{U} \\
\bar{U}\end{array}$ & $\begin{array}{r}10 \\
5 \\
- \\
- \\
5\end{array}$ & $\begin{array}{c}\bar{U} \\
\bar{U} \\
\bar{U}\end{array}$ & $\begin{array}{l}4 \\
- \\
- \\
- \\
4\end{array}$ & $\begin{array}{r}14 \\
5 \\
- \\
- \\
9\end{array}$ & $\begin{array}{l}- \\
- \\
- \\
- \\
-\end{array}$ \\
\hline $\begin{array}{l}\text { MOUNTAIN } \\
\text { Mont. } \\
\text { Idaho } \\
\text { Wyo. } \\
\text { Colo. } \\
\text { N. Mex. } \\
\text { Ariz. } \\
\text { Utah } \\
\text { Nev. }\end{array}$ & $\begin{array}{r}106 \\
3 \\
1 \\
1 \\
11 \\
19 \\
56 \\
11 \\
4\end{array}$ & $\begin{array}{r}117 \\
- \\
2 \\
1 \\
21 \\
8 \\
60 \\
6 \\
19\end{array}$ & $\begin{array}{r}1,251 \\
17 \\
45 \\
8 \\
208 \\
51 \\
725 \\
66 \\
131\end{array}$ & $\begin{array}{r}3,017 \\
94 \\
233 \\
37 \\
333 \\
148 \\
1,765 \\
190 \\
217\end{array}$ & $\begin{array}{r}545 \\
17 \\
29 \\
13 \\
92 \\
169 \\
140 \\
37 \\
48\end{array}$ & $\begin{array}{r}790 \\
5 \\
48 \\
10 \\
102 \\
309 \\
170 \\
65 \\
81\end{array}$ & $\begin{array}{l}- \\
- \\
- \\
- \\
- \\
- \\
-\end{array}$ & $\begin{array}{l}4 \\
- \\
- \\
- \\
- \\
- \\
1 \\
2 \\
1\end{array}$ & $\begin{array}{l}- \\
\\
- \\
- \\
- \\
- \\
-\end{array}$ & $\begin{array}{l}- \\
- \\
- \\
- \\
- \\
- \\
- \\
-\end{array}$ & $\begin{array}{l}4 \\
- \\
- \\
- \\
- \\
- \\
1 \\
2 \\
1\end{array}$ & $\begin{array}{l}5 \\
- \\
- \\
- \\
- \\
- \\
5 \\
- \\
-\end{array}$ \\
\hline $\begin{array}{l}\text { PACIFIC } \\
\text { Wash. } \\
\text { Oreg. } \\
\text { Calif. } \\
\text { Alaska } \\
\text { Hawaii }\end{array}$ & $\begin{array}{r}113 \\
7 \\
40 \\
48 \\
9 \\
9\end{array}$ & $\begin{array}{r}114 \\
9 \\
41 \\
50 \\
4 \\
10\end{array}$ & $\begin{array}{r}3,919 \\
377 \\
238 \\
3,271 \\
12 \\
21\end{array}$ & $\begin{array}{r}5,370 \\
928 \\
427 \\
3,944 \\
17 \\
54\end{array}$ & $\begin{array}{r}1,418 \\
74 \\
100 \\
1,213 \\
17 \\
14\end{array}$ & $\begin{array}{r}1,713 \\
108 \\
196 \\
1,378 \\
13 \\
18\end{array}$ & $\begin{array}{l}- \\
- \\
\bar{U} \\
- \\
-\end{array}$ & $\begin{array}{r}22 \\
- \\
9 \\
13 \\
- \\
-\end{array}$ & $\begin{array}{l}- \\
- \\
\text { U } \\
- \\
-\end{array}$ & $\begin{array}{l}6 \\
- \\
- \\
4 \\
- \\
2\end{array}$ & $\begin{array}{r}28 \\
- \\
9 \\
17 \\
- \\
2\end{array}$ & $\begin{array}{r}42 \\
1 \\
- \\
8 \\
33 \\
-\end{array}$ \\
\hline $\begin{array}{l}\text { Guam } \\
\text { P.R. } \\
\text { V.I. } \\
\text { Amer. Samoa } \\
\text { C.N.M.I. }\end{array}$ & $\begin{array}{l}- \\
\cup \\
U \\
U\end{array}$ & $\bigcup_{U}{ }_{U}^{-}$ & $\begin{array}{r}2 \\
215 \\
\cup \\
\cup\end{array}$ & $\begin{array}{r}1 \\
82 \\
\cup \\
\cup\end{array}$ & $\begin{array}{r}2 \\
160 \\
\cup \\
\cup\end{array}$ & $\begin{array}{r}2 \\
242 \\
U \\
U \\
U\end{array}$ & $\begin{array}{l}U \\
- \\
U \\
U \\
U\end{array}$ & $\begin{array}{l}1 \\
- \\
\cup \\
\cup\end{array}$ & $\begin{array}{l}U \\
- \\
U \\
U\end{array}$ & $\begin{array}{l}- \\
U \\
U\end{array}$ & $\begin{array}{l}1 \\
- \\
\cup \\
\cup\end{array}$ & $\begin{array}{c}- \\
\cup \\
U\end{array}$ \\
\hline
\end{tabular}

$\mathrm{N}$ : Not notifiable

U: Unavailable

-: no reported cases

*For imported measles, cases include only those resulting from importation from other countries.

${ }^{\dagger}$ Of 216 cases among children aged $<5$ years, serotype was reported for 109 and of those, 31 were type b. 
TABLE III. (Cont'd.) Provisional cases of selected notifiable diseases preventable by vaccination, United States, weeks ending December 18, 1999, and December 19, 1998 (50th Week)

\begin{tabular}{|c|c|c|c|c|c|c|c|c|c|c|c|}
\hline \multirow[b]{2}{*}{ Reporting Area } & \multicolumn{2}{|c|}{$\begin{array}{c}\text { Meningococcal } \\
\text { Disease }\end{array}$} & \multicolumn{3}{|c|}{ Mumps } & \multicolumn{3}{|c|}{ Pertussis } & \multicolumn{3}{|c|}{ Rubella } \\
\hline & $\begin{array}{l}\text { Cum. } \\
1999 \\
\end{array}$ & $\begin{array}{l}\text { Cum. } \\
1998\end{array}$ & 1999 & $\begin{array}{c}\text { Cum. } \\
1999 \\
\end{array}$ & $\begin{array}{l}\text { Cum. } \\
1998 \\
\end{array}$ & 1999 & $\begin{array}{l}\text { Cum. } \\
1999\end{array}$ & $\begin{array}{l}\text { Cum. } \\
1998 \\
\end{array}$ & 1999 & $\begin{array}{l}\text { Cum. } \\
1999\end{array}$ & $\begin{array}{l}\text { Cum. } \\
1998 \\
\end{array}$ \\
\hline UNITED STATES & 2,223 & 2,537 & 5 & 327 & 627 & 120 & 5,696 & 6,656 & - & 235 & 355 \\
\hline $\begin{array}{l}\text { NEW ENGLAND } \\
\text { Maine } \\
\text { N.H. } \\
\text { Vt. } \\
\text { Mass. } \\
\text { R.I. } \\
\text { Conn. }\end{array}$ & $\begin{array}{r}107 \\
5 \\
13 \\
5 \\
61 \\
7 \\
7 \\
16\end{array}$ & $\begin{array}{r}113 \\
7 \\
12 \\
5 \\
56 \\
8 \\
8 \\
25\end{array}$ & $\begin{array}{l}\bar{U} \\
- \\
- \\
- \\
-\end{array}$ & $\begin{array}{l}8 \\
- \\
1 \\
1 \\
4 \\
2 \\
-\end{array}$ & $\begin{array}{r}10 \\
- \\
- \\
- \\
6 \\
1 \\
3\end{array}$ & $\begin{array}{c}14 \\
U \\
- \\
5 \\
4 \\
5 \\
-\end{array}$ & $\begin{array}{r}78 \\
81 \\
492 \\
38 \\
31\end{array}$ & $\begin{array}{r}1,028 \\
5 \\
123 \\
78 \\
763 \\
13 \\
46\end{array}$ & $\begin{array}{l}\bar{U} \\
- \\
- \\
- \\
- \\
-\end{array}$ & $\begin{array}{l}7 \\
- \\
- \\
7 \\
- \\
-\end{array}$ & $\begin{array}{r}38 \\
- \\
- \\
- \\
8 \\
1 \\
29\end{array}$ \\
\hline $\begin{array}{l}\text { MID. ATLANTIC } \\
\text { Upstate N.Y. } \\
\text { N.Y. City } \\
\text { N.J. } \\
\text { Pa. }\end{array}$ & $\begin{array}{r}208 \\
68 \\
50 \\
47 \\
43\end{array}$ & $\begin{array}{r}274 \\
78 \\
33 \\
57 \\
106\end{array}$ & $\begin{array}{l}- \\
- \\
\end{array}$ & $\begin{array}{r}35 \\
14 \\
3 \\
- \\
18\end{array}$ & $\begin{array}{r}192 \\
13 \\
155 \\
6 \\
18\end{array}$ & $\begin{array}{r}40 \\
40 \\
- \\
\\
-\end{array}$ & $\begin{array}{r}953 \\
763 \\
10 \\
12 \\
168\end{array}$ & $\begin{array}{r}635 \\
330 \\
47 \\
29 \\
229\end{array}$ & $\begin{array}{l}- \\
- \\
\\
\end{array}$ & $\begin{array}{r}25 \\
21 \\
- \\
1 \\
3\end{array}$ & $\begin{array}{r}149 \\
114 \\
19 \\
14 \\
2\end{array}$ \\
\hline $\begin{array}{l}\text { E.N. CENTRAL } \\
\text { Ohio } \\
\text { Ind. } \\
\text { III. } \\
\text { Mich. } \\
\text { Wis. }\end{array}$ & $\begin{array}{r}377 \\
129 \\
69 \\
96 \\
45 \\
38\end{array}$ & $\begin{array}{r}389 \\
139 \\
72 \\
101 \\
44 \\
33\end{array}$ & $\begin{array}{l}3 \\
2 \\
- \\
1 \\
- \\
\end{array}$ & $\begin{array}{r}46 \\
20 \\
5 \\
12 \\
7 \\
2\end{array}$ & $\begin{array}{r}80 \\
29 \\
7 \\
10 \\
31 \\
3\end{array}$ & $\begin{array}{r}25 \\
23 \\
1 \\
- \\
1 \\
\cup\end{array}$ & $\begin{array}{r}567 \\
291 \\
75 \\
82 \\
67 \\
52\end{array}$ & $\begin{array}{r}843 \\
282 \\
173 \\
135 \\
70 \\
183\end{array}$ & $\begin{array}{l}- \\
- \\
- \\
- \\
\end{array}$ & $\begin{array}{l}2 \\
- \\
1 \\
1 \\
- \\
-\end{array}$ & $\begin{array}{l}- \\
- \\
- \\
- \\
-\end{array}$ \\
\hline $\begin{array}{l}\text { W.N. CENTRAL } \\
\text { Minn. } \\
\text { lowa } \\
\text { Mo. } \\
\text { N. Dak. } \\
\text { S. Dak. } \\
\text { Nebr. } \\
\text { Kans. }\end{array}$ & $\begin{array}{r}230 \\
50 \\
42 \\
93 \\
4 \\
11 \\
12 \\
18\end{array}$ & $\begin{array}{r}223 \\
35 \\
44 \\
78 \\
5 \\
8 \\
17 \\
36\end{array}$ & $\begin{array}{c}1 \\
\overline{1} \\
- \\
\\
- \\
\end{array}$ & $\begin{array}{r}14 \\
1 \\
8 \\
1 \\
1 \\
- \\
- \\
3\end{array}$ & $\begin{array}{r}33 \\
13 \\
11 \\
4 \\
2 \\
- \\
- \\
3\end{array}$ & $\begin{array}{l}3 \\
- \\
\overline{-} \\
\mathrm{U} \\
- \\
\bar{U}\end{array}$ & $\begin{array}{r}425 \\
226 \\
69 \\
64 \\
18 \\
7 \\
6 \\
35\end{array}$ & $\begin{array}{r}595 \\
342 \\
74 \\
48 \\
4 \\
8 \\
17 \\
102\end{array}$ & $\begin{array}{c}- \\
- \\
\bar{U} \\
- \\
\bar{U}\end{array}$ & $\begin{array}{r}127 \\
5 \\
29 \\
3 \\
- \\
- \\
90 \\
-\end{array}$ & $\begin{array}{r}40 \\
- \\
- \\
2 \\
- \\
- \\
- \\
38\end{array}$ \\
\hline $\begin{array}{l}\text { S. ATLANTIC } \\
\text { Del. } \\
\text { Md. } \\
\text { D.C. } \\
\text { Va. } \\
\text { W. Va. } \\
\text { N.C. } \\
\text { S.C. } \\
\text { Ga. } \\
\text { Fla. }\end{array}$ & $\begin{array}{r}412 \\
8 \\
54 \\
2 \\
55 \\
8 \\
46 \\
44 \\
61 \\
134\end{array}$ & $\begin{array}{r}435 \\
2 \\
34 \\
3 \\
48 \\
18 \\
57 \\
57 \\
97 \\
119\end{array}$ & $\begin{array}{l}- \\
- \\
- \\
- \\
- \\
- \\
\\
- \\
-\end{array}$ & $\begin{array}{r}50 \\
- \\
7 \\
2 \\
10 \\
- \\
8 \\
5 \\
4 \\
14\end{array}$ & $\begin{array}{r}49 \\
- \\
- \\
- \\
10 \\
- \\
11 \\
7 \\
1 \\
20\end{array}$ & $\begin{array}{l}9 \\
1 \\
- \\
- \\
- \\
- \\
\\
1 \\
-\end{array}$ & $\begin{array}{r}417 \\
6 \\
107 \\
1 \\
51 \\
3 \\
93 \\
19 \\
40 \\
97\end{array}$ & $\begin{array}{r}338 \\
5 \\
65 \\
1 \\
50 \\
4 \\
103 \\
27 \\
27 \\
56\end{array}$ & $\begin{array}{l}- \\
- \\
- \\
- \\
- \\
\bar{U} \\
- \\
-\end{array}$ & $\begin{array}{r}37 \\
- \\
1 \\
- \\
- \\
35 \\
- \\
- \\
1\end{array}$ & $\begin{array}{r}19 \\
- \\
1 \\
- \\
1 \\
13 \\
- \\
- \\
4\end{array}$ \\
\hline $\begin{array}{l}\text { E.S. CENTRAL } \\
\text { Ky. } \\
\text { Tenn. } \\
\text { Ala. } \\
\text { Miss. }\end{array}$ & $\begin{array}{r}148 \\
32 \\
59 \\
33 \\
24\end{array}$ & $\begin{array}{r}197 \\
37 \\
69 \\
54 \\
37\end{array}$ & $\begin{array}{l}1 \\
U \\
- \\
1 \\
-\end{array}$ & $\begin{array}{r}14 \\
- \\
11 \\
3\end{array}$ & $\begin{array}{r}19 \\
1 \\
2 \\
9 \\
7\end{array}$ & $\begin{array}{l}\bar{U} \\
- \\
- \\
-\end{array}$ & $\begin{array}{r}88 \\
25 \\
40 \\
21 \\
2\end{array}$ & $\begin{array}{r}155 \\
85 \\
37 \\
27 \\
6\end{array}$ & $\begin{array}{l}\bar{U} \\
- \\
-\end{array}$ & $\begin{array}{l}1 \\
- \\
- \\
1 \\
-\end{array}$ & $\begin{array}{l}2 \\
- \\
2 \\
- \\
-\end{array}$ \\
\hline $\begin{array}{l}\text { W.S. CENTRAL } \\
\text { Ark. } \\
\text { La. } \\
\text { Okla. } \\
\text { Tex. }\end{array}$ & $\begin{array}{r}174 \\
35 \\
34 \\
31 \\
74\end{array}$ & $\begin{array}{r}294 \\
31 \\
56 \\
41 \\
166\end{array}$ & $\begin{array}{c}\bar{U} \\
\bar{U}\end{array}$ & $\begin{array}{r}33 \\
- \\
3 \\
1 \\
29\end{array}$ & $\begin{array}{r}60 \\
13 \\
7 \\
- \\
40\end{array}$ & $\begin{array}{c}\bar{U} \\
\bar{U}\end{array}$ & $\begin{array}{r}158 \\
19 \\
3 \\
12 \\
124\end{array}$ & $\begin{array}{r}364 \\
84 \\
9 \\
33 \\
238\end{array}$ & $\begin{array}{c}\bar{U} \\
\bar{U}\end{array}$ & $\begin{array}{r}15 \\
6 \\
- \\
9\end{array}$ & $\begin{array}{r}89 \\
- \\
- \\
- \\
89\end{array}$ \\
\hline $\begin{array}{l}\text { MOUNTAIN } \\
\text { Mont. } \\
\text { Idaho } \\
\text { Wyo. } \\
\text { Colo. } \\
\text { N. Mex. } \\
\text { Ariz. } \\
\text { Utah } \\
\text { Nev. }\end{array}$ & $\begin{array}{r}139 \\
4 \\
13 \\
5 \\
36 \\
15 \\
42 \\
16 \\
8\end{array}$ & $\begin{array}{r}146 \\
4 \\
13 \\
8 \\
29 \\
26 \\
43 \\
13 \\
10\end{array}$ & $\begin{array}{c}- \\
\\
- \\
\bar{N} \\
- \\
\bar{U}\end{array}$ & $\begin{array}{r}28 \\
- \\
3 \\
- \\
5 \\
N \\
8 \\
7 \\
5\end{array}$ & $\begin{array}{r}40 \\
- \\
7 \\
1 \\
7 \\
N \\
6 \\
5 \\
14\end{array}$ & $\begin{array}{r}22 \\
U \\
1 \\
- \\
6 \\
9 \\
5 \\
1 \\
U\end{array}$ & $\begin{array}{r}761 \\
2 \\
140 \\
2 \\
213 \\
210 \\
122 \\
61 \\
11\end{array}$ & $\begin{array}{r}1,207 \\
13 \\
239 \\
8 \\
341 \\
98 \\
201 \\
266 \\
41\end{array}$ & $\begin{array}{l}- \\
\\
- \\
- \\
- \\
- \\
\end{array}$ & $\begin{array}{r}16 \\
- \\
- \\
- \\
1 \\
- \\
13 \\
1 \\
1\end{array}$ & $\begin{array}{l}5 \\
- \\
- \\
- \\
- \\
1 \\
1 \\
2 \\
1\end{array}$ \\
\hline $\begin{array}{l}\text { PACIFIC } \\
\text { Wash. } \\
\text { Oreg. } \\
\text { Calif. } \\
\text { Alaska } \\
\text { Hawaii }\end{array}$ & $\begin{array}{r}428 \\
65 \\
77 \\
271 \\
6 \\
9\end{array}$ & $\begin{array}{r}466 \\
64 \\
87 \\
307 \\
3 \\
5\end{array}$ & $\begin{array}{l}- \\
- \\
\mathrm{N} \\
- \\
-\end{array}$ & $\begin{array}{r}99 \\
2 \\
\mathrm{~N} \\
82 \\
3 \\
12\end{array}$ & $\begin{array}{r}144 \\
11 \\
\mathrm{~N} \\
106 \\
3 \\
24\end{array}$ & $\begin{array}{r}7 \\
7 \\
- \\
\\
- \\
-\end{array}$ & $\begin{array}{r}1,607 \\
616 \\
58 \\
894 \\
5 \\
34\end{array}$ & $\begin{array}{r}1,491 \\
330 \\
89 \\
1,032 \\
15 \\
25\end{array}$ & $\begin{array}{l}- \\
- \\
\\
\end{array}$ & $\begin{array}{l}5 \\
- \\
5 \\
5 \\
- \\
-\end{array}$ & $\begin{array}{r}13 \\
8 \\
- \\
3 \\
- \\
2\end{array}$ \\
\hline $\begin{array}{l}\text { Guam } \\
\text { P.R. } \\
\text { V.I. } \\
\text { Amer. Samoa } \\
\text { C.N.M.I. }\end{array}$ & $\begin{array}{l}2 \\
8 \\
U \\
U\end{array}$ & $\begin{array}{r}2 \\
11 \\
U \\
U\end{array}$ & $\begin{array}{l}U \\
- \\
U \\
U \\
U\end{array}$ & $\begin{array}{l}1 \\
- \\
U \\
U \\
U\end{array}$ & $\begin{array}{l}5 \\
7 \\
\cup \\
\cup\end{array}$ & $\begin{array}{l}U \\
\dot{U} \\
U \\
U\end{array}$ & $\begin{array}{r}1 \\
20 \\
U \\
U \\
U\end{array}$ & $\begin{array}{l}1 \\
9 \\
U \\
\cup\end{array}$ & $\begin{array}{c}U \\
\bar{U} \\
U \\
U\end{array}$ & $\begin{array}{c}- \\
U \\
U\end{array}$ & $\begin{array}{l}14 \\
\cup\end{array}$ \\
\hline
\end{tabular}

$\mathrm{N}$ : Not notifiable

U: Unavailable

-: no reported cases 
TABLE IV. Deaths in 122 U.S. cities, ${ }^{*}$ week ending December 18, 1999 (50th Week)

\begin{tabular}{|c|c|c|c|c|c|c|c|c|c|c|c|c|c|c|c|}
\hline \multirow[b]{2}{*}{ Reporting Area } & \multicolumn{6}{|c|}{ All Causes, By Age (Years) } & \multirow{2}{*}{$\begin{array}{l}\text { P\&l } \\
\text { Total }\end{array}$} & \multirow[b]{2}{*}{ Reporting Area } & \multicolumn{6}{|c|}{ All Causes, By Age (Years) } & \multirow{2}{*}{$\begin{array}{l}\text { P\&I }^{\dagger} \\
\text { Total }\end{array}$} \\
\hline & $\begin{array}{c}\text { All } \\
\text { Ages }\end{array}$ & $\geq 65$ & $45-64$ & $25-44$ & $1-24$ & $<1$ & & & $\begin{array}{c}\text { All } \\
\text { Ages }\end{array}$ & $\geq 65$ & $45-64$ & $25-44$ & $1-24$ & $<1$ & \\
\hline $\begin{array}{l}\text { NEW ENGLAND } \\
\text { Boston, Mass. } \\
\text { Bridgeport, Conn. } \\
\text { Cambridge, Mass. } \\
\text { Fall River, Mass. } \\
\text { Hartford, Conn. } \\
\text { Lowell, Mass. } \\
\text { Lynn, Mass. } \\
\text { New Bedford, Mass. } \\
\text { New Haven, Conn. } \\
\text { Providence, R.I. } \\
\text { Somerville, Mass. } \\
\text { Springfield, Mass. } \\
\text { Waterbury, Conn. } \\
\text { Worcester, Mass. }\end{array}$ & $\begin{array}{r}461 \\
\text { U } \\
47 \\
16 \\
19 \\
51 \\
29 \\
11 \\
21 \\
34 \\
81 \\
5 \\
31 \\
53 \\
63\end{array}$ & $\begin{array}{r}341 \\
\text { U } \\
39 \\
11 \\
18 \\
39 \\
26 \\
4 \\
17 \\
25 \\
53 \\
4 \\
25 \\
37 \\
43\end{array}$ & $\begin{array}{r}72 \\
\text { U } \\
7 \\
4 \\
1 \\
8 \\
2 \\
4 \\
3 \\
3 \\
18 \\
1 \\
2 \\
10 \\
9\end{array}$ & $\begin{array}{l}38 \\
U \\
1 \\
1 \\
- \\
4 \\
- \\
3 \\
1 \\
4 \\
8 \\
- \\
3 \\
4 \\
9\end{array}$ & $\begin{array}{l}5 \\
\text { U } \\
- \\
- \\
- \\
- \\
- \\
- \\
- \\
1 \\
- \\
- \\
- \\
2 \\
2\end{array}$ & $\begin{array}{l}5 \\
U \\
- \\
- \\
- \\
- \\
1 \\
- \\
- \\
1 \\
2 \\
- \\
1 \\
- \\
-\end{array}$ & $\begin{array}{l}46 \\
U \\
5 \\
- \\
2 \\
8 \\
3 \\
- \\
3 \\
4 \\
5 \\
2 \\
4 \\
3 \\
7\end{array}$ & $\begin{array}{l}\text { S. ATLANTIC } \\
\text { Atlanta, Ga. } \\
\text { Baltimore, Md. } \\
\text { Charlotte, N.C. } \\
\text { Jacksonville, Fla. } \\
\text { Miami, Fla. } \\
\text { Norfolk, Va. } \\
\text { Richmond, Va. } \\
\text { Savannah, Ga. } \\
\text { St. Petersburg, Fla. } \\
\text { Tampa, Fla. } \\
\text { Washington, D.C. } \\
\text { Wilmington, Del. } \\
\text { E.S. CENTRAL } \\
\text { Birmingham Ala }\end{array}$ & $\begin{array}{r}1,051 \\
U \\
237 \\
100 \\
150 \\
107 \\
52 \\
U \\
49 \\
88 \\
243 \\
U \\
25 \\
972 \\
197\end{array}$ & $\begin{array}{r}692 \\
U \\
139 \\
76 \\
108 \\
58 \\
28 \\
U \\
33 \\
66 \\
169 \\
U \\
15\end{array}$ & $\begin{array}{r}232 \\
U \\
57 \\
21 \\
27 \\
27 \\
15 \\
U \\
10 \\
15 \\
50 \\
U \\
10\end{array}$ & $\begin{array}{r}76 \\
U \\
25 \\
2 \\
7 \\
16 \\
5 \\
U \\
2 \\
4 \\
15 \\
U \\
-\end{array}$ & $\begin{array}{r}29 \\
U \\
12 \\
1 \\
4 \\
5 \\
1 \\
U \\
3 \\
1 \\
2 \\
U \\
-\end{array}$ & $\begin{array}{r}21 \\
U \\
4 \\
- \\
3 \\
1 \\
3 \\
U \\
1 \\
2 \\
7 \\
U \\
-\end{array}$ & $\begin{array}{r}95 \\
U \\
22 \\
11 \\
15 \\
10 \\
- \\
U \\
8 \\
6 \\
23 \\
U \\
-\end{array}$ \\
\hline $\begin{array}{l}\text { MID. ATLANTIC } \\
\text { Albany, N.Y. } \\
\text { Allentown, Pa. } \\
\text { Buffalo, N.Y. } \\
\text { Camden, N.J. } \\
\text { Elizabeth, N.J. } \\
\text { Erie, Pa. }\end{array}$ & $\begin{array}{r}2,320 \\
57 \\
U \\
52 \\
21 \\
21 \\
49\end{array}$ & $\begin{array}{r}1,634 \\
46 \\
U \\
39 \\
16 \\
18 \\
31\end{array}$ & $\begin{array}{r}431 \\
8 \\
U \\
9 \\
4 \\
2 \\
13\end{array}$ & $\begin{array}{r}168 \\
3 \\
U \\
1 \\
1 \\
- \\
3\end{array}$ & $\begin{array}{r}44 \\
- \\
\text { U } \\
- \\
1 \\
2\end{array}$ & $\begin{array}{r}42 \\
- \\
\text { U } \\
3 \\
- \\
- \\
-\end{array}$ & $\begin{array}{r}95 \\
4 \\
U \\
7 \\
1 \\
1 \\
2\end{array}$ & $\begin{array}{l}\text { Chattanooga, Tenn. } \\
\text { Knoxville, Tenn. } \\
\text { Lexington, Ky. } \\
\text { Memphis, Tenn. } \\
\text { Mobile, Ala. } \\
\text { Montgomery, Ala. } \\
\text { Nashville, Tenn. }\end{array}$ & $\begin{array}{r}105 \\
116 \\
75 \\
179 \\
108 \\
50 \\
142\end{array}$ & $\begin{array}{r}105 \\
80 \\
83 \\
44 \\
119 \\
73 \\
31 \\
98\end{array}$ & $\begin{array}{l}30 \\
15 \\
23 \\
21 \\
44 \\
29 \\
15 \\
26\end{array}$ & $\begin{array}{r}1 \\
9 \\
8 \\
5 \\
10 \\
6 \\
4 \\
11\end{array}$ & $\begin{array}{l}4 \\
1 \\
2 \\
1 \\
4 \\
- \\
- \\
3\end{array}$ & $\begin{array}{l}- \\
- \\
4 \\
2 \\
- \\
- \\
4\end{array}$ & $\begin{array}{r}10 \\
10 \\
10 \\
6 \\
14 \\
6 \\
6 \\
9\end{array}$ \\
\hline $\begin{array}{l}\text { Jersey City, N.J. } \\
\text { New York City, N.Y. } \\
\text { Newark, N.J. } \\
\text { Paterson, N.J. } \\
\text { Philadelphia, Pa. } \\
\text { Pittsburgh, Pa.§ } \\
\text { Reading, Pa. } \\
\text { Rochester, N.Y. } \\
\text { Schenectady, N.Y. } \\
\text { Scranton, Pa. } \\
\text { Syracuse, N.Y. } \\
\text { Trenton, N.J. } \\
\text { Utica, N.Y. } \\
\text { Yonkers, N.Y. }\end{array}$ & $\begin{array}{r}33 \\
1,241 \\
65 \\
18 \\
300 \\
72 \\
36 \\
143 \\
31 \\
35 \\
104 \\
27 \\
15 \\
U\end{array}$ & $\begin{array}{r}23 \\
867 \\
28 \\
11 \\
200 \\
49 \\
26 \\
114 \\
23 \\
30 \\
81 \\
18 \\
14 \\
U\end{array}$ & $\begin{array}{r}6 \\
241 \\
18 \\
4 \\
56 \\
11 \\
6 \\
21 \\
5 \\
3 \\
18 \\
5 \\
1 \\
U\end{array}$ & $\begin{array}{r}4 \\
88 \\
18 \\
2 \\
30 \\
6 \\
2 \\
3 \\
2 \\
1 \\
1 \\
3 \\
-\end{array}$ & $\begin{array}{r}- \\
20 \\
1 \\
- \\
8 \\
6 \\
1 \\
3 \\
1 \\
1 \\
- \\
- \\
-\end{array}$ & $\begin{array}{r}- \\
24 \\
\overline{1} \\
6 \\
- \\
1 \\
2 \\
- \\
- \\
4 \\
1 \\
-\end{array}$ & $\begin{array}{r}25 \\
25 \\
4 \\
- \\
16 \\
4 \\
3 \\
13 \\
- \\
3 \\
10 \\
2 \\
- \\
\end{array}$ & $\begin{array}{l}\text { W.S. CENTRAL } \\
\text { Austin, Tex. } \\
\text { Baton Rouge, La. } \\
\text { Corpus Christi, Tex. } \\
\text { Dallas, Tex. } \\
\text { El Paso, Tex. } \\
\text { Ft. Worth, Tex. } \\
\text { Houston, Tex. } \\
\text { Little Rock, Ark. } \\
\text { New Orleans, La. } \\
\text { San Antonio, Tex. } \\
\text { Shreveport, La. } \\
\text { Tulsa, Okla. }\end{array}$ & $\begin{array}{r}1,545 \\
78 \\
55 \\
60 \\
190 \\
89 \\
121 \\
435 \\
60 \\
U \\
240 \\
73 \\
144\end{array}$ & $\begin{array}{r}1,015 \\
48 \\
29 \\
39 \\
118 \\
51 \\
82 \\
308 \\
41 \\
U \\
152 \\
54 \\
93\end{array}$ & $\begin{array}{r}342 \\
17 \\
11 \\
11 \\
39 \\
25 \\
30 \\
92 \\
13 \\
\mathrm{U} \\
51 \\
17 \\
36\end{array}$ & $\begin{array}{r}108 \\
7 \\
7 \\
5 \\
22 \\
8 \\
6 \\
23 \\
1 \\
U \\
17 \\
1 \\
11\end{array}$ & $\begin{array}{r}37 \\
4 \\
2 \\
2 \\
10 \\
3 \\
1 \\
4 \\
1 \\
U \\
8 \\
- \\
2\end{array}$ & $\begin{array}{r}43 \\
2 \\
6 \\
3 \\
1 \\
2 \\
2 \\
8 \\
4 \\
U \\
12 \\
1 \\
2\end{array}$ & $\begin{array}{r}125 \\
1 \\
3 \\
9 \\
4 \\
9 \\
9 \\
50 \\
5 \\
U \\
16 \\
7 \\
12\end{array}$ \\
\hline $\begin{array}{l}\text { E.N. CENTRAL } \\
\text { Akron, Ohio } \\
\text { Canton, Ohio } \\
\text { Chicago, Ill. } \\
\text { Cincinnati, Ohio } \\
\text { Cleveland, Ohio } \\
\text { Columbus, Ohio } \\
\text { Dayton, Ohio } \\
\text { Detroit, Mich. } \\
\text { Evansville, Ind. } \\
\text { Fort Wayne, Ind. }\end{array}$ & $\begin{array}{r}2,050 \\
51 \\
35 \\
382 \\
101 \\
147 \\
174 \\
122 \\
193 \\
15 \\
60\end{array}$ & $\begin{array}{r}1,408 \\
34 \\
29 \\
232 \\
68 \\
102 \\
128 \\
91 \\
116 \\
13 \\
47\end{array}$ & $\begin{array}{r}386 \\
8 \\
4 \\
88 \\
17 \\
28 \\
28 \\
20 \\
46 \\
2 \\
7\end{array}$ & $\begin{array}{r}152 \\
4 \\
2 \\
39 \\
4 \\
9 \\
11 \\
8 \\
19 \\
- \\
6\end{array}$ & $\begin{array}{r}52 \\
4 \\
- \\
15 \\
2 \\
2 \\
3 \\
2 \\
6 \\
- \\
-\end{array}$ & $\begin{array}{r}50 \\
1 \\
- \\
6 \\
10 \\
6 \\
4 \\
1 \\
6 \\
- \\
-\end{array}$ & $\begin{array}{r}158 \\
6 \\
3 \\
32 \\
7 \\
6 \\
21 \\
8 \\
11 \\
4 \\
4\end{array}$ & $\begin{array}{l}\text { MOUNTAIN } \\
\text { Albuquerque, N.M. } \\
\text { Boise, Idaho } \\
\text { Colo. Springs, Colo. } \\
\text { Denver, Colo. } \\
\text { Las Vegas, Nev. } \\
\text { Ogden, Utah } \\
\text { Phoenix, Ariz. } \\
\text { Pueblo, Colo. } \\
\text { Salt Lake City, Utah } \\
\text { Tucson, Ariz. }\end{array}$ & $\begin{array}{r}1,134 \\
131 \\
43 \\
81 \\
115 \\
235 \\
27 \\
182 \\
39 \\
105 \\
176\end{array}$ & $\begin{array}{r}786 \\
91 \\
33 \\
60 \\
83 \\
161 \\
22 \\
111 \\
28 \\
68 \\
129\end{array}$ & $\begin{array}{r}227 \\
29 \\
5 \\
11 \\
22 \\
47 \\
3 \\
50 \\
8 \\
20 \\
32\end{array}$ & $\begin{array}{r}88 \\
9 \\
4 \\
7 \\
7 \\
16 \\
2 \\
17 \\
3 \\
10 \\
13\end{array}$ & $\begin{array}{r}22 \\
1 \\
- \\
3 \\
3 \\
9 \\
- \\
2 \\
- \\
3 \\
1\end{array}$ & $\begin{array}{r}11 \\
1 \\
1 \\
- \\
- \\
2 \\
- \\
2 \\
- \\
4 \\
1\end{array}$ & $\begin{array}{r}119 \\
22 \\
7 \\
5 \\
7 \\
23 \\
1 \\
20 \\
3 \\
17 \\
14\end{array}$ \\
\hline $\begin{array}{l}\text { Gary, Ind. } \\
\text { Grand Rapids, Mich. } \\
\text { Indianapolis, Ind. } \\
\text { Lansing, Mich. } \\
\text { Milwaukee, Wis. } \\
\text { Peoria, III. } \\
\text { Rockford, III. } \\
\text { South Bend, Ind. } \\
\text { Toledo, Ohio } \\
\text { Youngstown, Ohio }\end{array}$ & $\begin{array}{r}11 \\
42 \\
170 \\
38 \\
132 \\
52 \\
70 \\
57 \\
127 \\
71\end{array}$ & $\begin{array}{r}5 \\
26 \\
115 \\
30 \\
96 \\
40 \\
53 \\
46 \\
85 \\
52\end{array}$ & $\begin{array}{r}4 \\
9 \\
34 \\
6 \\
17 \\
8 \\
11 \\
8 \\
29 \\
12\end{array}$ & $\begin{array}{r}2 \\
6 \\
11 \\
- \\
13 \\
- \\
4 \\
2 \\
9 \\
3\end{array}$ & $\begin{array}{l}- \\
1 \\
4 \\
2 \\
2 \\
4 \\
- \\
1 \\
3 \\
1\end{array}$ & $\begin{array}{l}- \\
- \\
6 \\
- \\
4 \\
- \\
2 \\
- \\
1 \\
3\end{array}$ & $\begin{array}{r}- \\
6 \\
14 \\
6 \\
8 \\
3 \\
5 \\
3 \\
10 \\
1\end{array}$ & $\begin{array}{l}\text { PACIFIC } \\
\text { Berkeley, Calif. } \\
\text { Fresno, Calif. } \\
\text { Glendale, Calif. } \\
\text { Honolulu, Hawaii } \\
\text { Long Beach, Calif. } \\
\text { Los Angeles, Calif. } \\
\text { Pasadena, Calif. } \\
\text { Portland, Oreg. } \\
\text { Sacramento, Calif. }\end{array}$ & $\begin{array}{r}1,416 \\
12 \\
108 \\
9 \\
82 \\
81 \\
251 \\
34 \\
121 \\
\mathrm{U}\end{array}$ & $\begin{array}{r}1,049 \\
9 \\
79 \\
6 \\
60 \\
54 \\
176 \\
31 \\
92 \\
\mathrm{U}\end{array}$ & $\begin{array}{r}241 \\
2 \\
23 \\
3 \\
15 \\
19 \\
45 \\
3 \\
22 \\
\mathrm{U}\end{array}$ & $\begin{array}{r}83 \\
- \\
6 \\
- \\
4 \\
5 \\
17 \\
- \\
5 \\
\text { U }\end{array}$ & $\begin{array}{r}23 \\
- \\
- \\
- \\
1 \\
1 \\
9 \\
- \\
1 \\
U\end{array}$ & $\begin{array}{r}19 \\
1 \\
- \\
- \\
2 \\
2 \\
4 \\
- \\
1 \\
\text { U }\end{array}$ & $\begin{array}{r}142 \\
2 \\
10 \\
- \\
13 \\
12 \\
7 \\
6 \\
8 \\
U\end{array}$ \\
\hline $\begin{array}{l}\text { W.N. CENTRAL } \\
\text { Des Moines, lowa } \\
\text { Duluth, Minn. } \\
\text { Kansas City, Kans. } \\
\text { Kansas City, Mo. } \\
\text { Lincoln, Nebr. } \\
\text { Minneapolis, Minn. }\end{array}$ & $\begin{array}{r}958 \\
146 \\
28 \\
29 \\
108 \\
35 \\
188\end{array}$ & $\begin{array}{r}670 \\
106 \\
23 \\
14 \\
73 \\
28 \\
147\end{array}$ & $\begin{array}{r}181 \\
26 \\
4 \\
10 \\
24 \\
5 \\
24\end{array}$ & $\begin{array}{r}57 \\
8 \\
1 \\
3 \\
7 \\
1 \\
8\end{array}$ & $\begin{array}{r}36 \\
3 \\
- \\
1 \\
4 \\
1 \\
7\end{array}$ & $\begin{array}{r}14 \\
3 \\
- \\
1 \\
- \\
- \\
2\end{array}$ & $\begin{array}{r}74 \\
10 \\
3 \\
2 \\
9 \\
2 \\
23\end{array}$ & $\begin{array}{l}\text { San Diego, Calif. } \\
\text { San Francisco, Calif. } \\
\text { San Jose, Calif. } \\
\text { Santa Cruz, Calif. } \\
\text { Seattle, Wash. } \\
\text { Spokane, Wash. } \\
\text { Tacoma, Wash. }\end{array}$ & $\begin{array}{r}138 \\
U \\
229 \\
38 \\
148 \\
69 \\
96\end{array}$ & $\begin{array}{r}101 \\
U \\
183 \\
26 \\
102 \\
56 \\
74\end{array}$ & $\begin{array}{r}23 \\
U \\
26 \\
7 \\
30 \\
10 \\
13\end{array}$ & $\begin{array}{r}11 \\
U \\
12 \\
5 \\
11 \\
2 \\
5\end{array}$ & $\begin{array}{l}1 \\
U \\
5 \\
- \\
3 \\
- \\
2\end{array}$ & $\begin{array}{l}2 \\
U \\
3 \\
- \\
2 \\
1 \\
1\end{array}$ & $\begin{array}{r}14 \\
U \\
33 \\
3 \\
15 \\
10 \\
9\end{array}$ \\
\hline $\begin{array}{l}\text { Omaha, Nebr. } \\
\text { St. Louis, Mo. } \\
\text { St. Paul, Minn. } \\
\text { Wichita, Kans. }\end{array}$ & $\begin{array}{r}100 \\
104 \\
121 \\
82 \\
117\end{array}$ & $\begin{array}{l}141 \\
74 \\
65 \\
63 \\
77\end{array}$ & $\begin{array}{l}24 \\
14 \\
38 \\
14 \\
22\end{array}$ & $\begin{array}{r}10 \\
8 \\
3 \\
8\end{array}$ & $\begin{array}{l}6 \\
4 \\
2 \\
8\end{array}$ & $\begin{array}{l}- \\
6 \\
- \\
2\end{array}$ & $\begin{array}{r}13 \\
- \\
8 \\
4\end{array}$ & TOTAL & $11,907^{\text {【 }}$ & 8,262 & 2,323 & 834 & 263 & 220 & 930 \\
\hline
\end{tabular}

U: Unavailable -: no reported cases

* Mortality data in this table are voluntarily reported from 122 cities in the United States, most of which have populations of 100,000 or more. A death is reported by the place of its occurrence and by the week that the death certificate was filed. Fetal deaths are not included.

†Pneumonia and influenza.

${ }^{\S}$ Because of changes in reporting methods in this Pennsylvania city, these numbers are partial counts for the current week. Complete counts will be available in 4 to 6 weeks.

ITotal includes unknown ages. 
Contributors to the Production of the MMWR (Weekly)

Weekly Notifiable Disease Morbidity Data and 122 Cities Mortality Data

Samuel L. Groseclose, D.V.M., M.P.H.

State Support Team

Robert Fagan

Jose Aponte

Paul Gangarosa, M.P.H

Gerald Jones

David Nitschke

Carol A. Worsham
CDC Operations Team

Carol M. Knowles

Deborah A. Adams

Willie J. Anderson

Patsy A. Hall

Kathryn Snavely

Sara Zywicki 
The Morbidity and Mortality Weekly Report (MMWR) Series is prepared by the Centers for Disease Control and Prevention (CDC) and is available free of charge in electronic format and on a paid subscription basis for paper copy. To receive an electronic copy on Friday of each week, send an e-mail message to listserv@listserv.cdc.gov. The body content should read SUBscribe mmwr-toc. Electronic copy also is available from CDC's World-Wide Web server at http://www.cdc.gov/ or from CDC's file transfer protocol server at ftp.cdc.gov. To subscribe for paper copy, contact Superintendent of Documents, U.S. Government Printing Office, Washington, DC 20402; telephone (202) 512-1800.

Data in the weekly MMWR are provisional, based on weekly reports to CDC by state health departments. The reporting week concludes at close of business on Friday; compiled data on a national basis are officially released to the public on the following Friday. Address inquiries about the MMWR Series, including material to be considered for publication, to: Editor, MMWR Series, Mailstop C-08, CDC, 1600 Clifton Rd., N.E., Atlanta, GA 30333; telephone (888) 232-3228.

All material in the MMWR Series is in the public domain and may be used and reprinted without permission; citation as to source, however, is appreciated.

Director, Centers for Disease Control Acting Director, and Prevention

Jeffrey P. Koplan, M.D., M.P.H.

Acting Deputy Director for Science

and Public Health, Centers for

Disease Control and Prevention

Lynne S. Wilcox, M.D., M.P.H.

\section{Epidemiology Program Office}

Barbara R. Holloway, M.P.H.

Editor, MMWR Series John W. Ward, M.D.

Managing Editor

MMWR (weekly)

Karen L. Foster, M.A.
Writers-Editors, $M M W R$ (weekly)

Jill Crane

David C. Johnson

Teresa F. Rutledge

Caran R. Wilbanks

Desktop Publishing Morie M. Higgins 